Carona, C., Silva, N., \& Moreira, H. (2015). Applying a developmental approach to quality of life assessment in children and adolescents with psychological disorders: Challenges and guidelines. Expert Review of

Pharmacoeconomics \& Outcomes Research, 15, 47-70. Invited paper. doi: 10.1586/14737167.2015.972377

\title{
Applying a Developmental Approach to Quality of Life Assessment in Children and Adolescents with Psychological Disorders: Challenges and Guidelines
}

\begin{abstract}
Research on the quality of life (QL) of children/adolescents with psychological disorders has flourished over the last few decades. Given the developmental challenges of QL measurements in pediatric populations, the aim of this study was to ascertain the extent to which a developmental approach to QL assessment has been applied to pedopsychiatric QL research. A systematic literature search was conducted in three electronic databases (PubMed, PsycINFO,SocINDEX) from 1994 to May 2014. Quantitative studies were included if they assessed the self or proxy-reported QL of children/adolescents with a psychological disorder. Data were extracted for study design, participants, QL instruments and informants, and statistical approach to age-related specificities. The systematic review revealed widespread utilization of developmentally appropriate QL instruments but less frequent use of both self and proxy reports and an inconsistent approach to age group specificities. Methodological guidelines are discussed to improve the developmental validity of QL research for children/adolescents with mental disorders.
\end{abstract}

Keywords: Children and adolescents, Developmental approach, Pedopsychiatry, Patient- and proxyreported outcomes, Pediatric psychological disorders, Quality of life assessment. 


\section{Introduction}

In clinical and research settings, the assessment of quality of life (QL) in children and adolescents has progressed more slowly than in adult populations due to a number of conceptual and methodological considerations, such as the inclusion of developmental specificities, the ascertainment of children's cognitive abilities and the selection of respondents (self or proxy sources of information) [1]. These considerations have become particularly prominent for the measurement of QL in children and adolescents with psychological disorders. First, the prevalence of childhood psychiatric disorders may be considerably underestimated [2]; thus, it may receive less attention in clinical research and practice. Second, given the homotypic and heterotypic continuity of psychological disorders from childhood to adolescence [3], the appraisal of common QL markers is particularly warranted to enable comparisons in longitudinal assessments across both developmental periods. Third, cognitive abilities, such as perception, attention and memory, are inherently affected during emotional disturbance states. Hence, there is a distinctive need to adopt multi-respondent designs in QL assessments. This approach has been cited as a central methodological tenet in developmental psychopathology [4]. In fact, when establishing general guidelines for conducting QL assessments in children, the World Health Organization (WHO) stated that the assessments should be age-related or at least developmentally appropriate [5]. Since then, a developmental approach to QL assessment has been reiterated and gradually refined [6-9]. Two core recommendations have been maintained: the first relates to the acknowledgement of specificities and commonalties in the assessment of children's and adolescents' QL, and the second suggests selective or complementary use of self-reports and proxy reports. Given the aforementioned challenges for QL assessment in pediatric patients with psychological disorders, there is renewed interest in examining the extent to which the operationalization of a developmental approach has been successfully applied to QL assessments in this specific pediatric population. Such an examination is likely to identify current research strengths and gaps and provide crucial insight on how to improve the developmental validity of QL assessments in children and adolescents with psychological disorders.

QL has been defined by the WHO as "an individual's perception of their position in life in the context of the cultural and values systems in which they live, and in relation to their goals, 
expectations, standards and concerns" [10, p.153]. QL can be seen as a multidimensional construct encompassing a variety of core domains, such as physical health, functional status, emotional wellbeing, social relationships, and material living conditions [11]. Despite the fact that research on the QL of pedopsychiatric patients is still in its infancy [12], available evidence indicates that children and adolescents with psychological disorders not only have more impaired QL than their peers from the general population but also that their QL is comparable to or even poorer than pediatric patients with physical conditions [13-14].

Psychological (or mental) disorders are defined as a "clinically recognizable set of symptoms or behaviors associated in most cases with distress and interference with personal functions" $[15$, p.11]. Although these disorders tend to be underdiagnosed in younger populations, most of them typically begin during youth, and they account for a large proportion of the disease burden in children and adolescents worldwide [16]. Moreover, inadequate appreciation of the interplay between mental disorders and other health conditions has motivated the WHO's claim that there can be "no health without mental health" [17, p.859]. Nevertheless, although the aims of treatment for psychological disorders are to reduce symptoms, increase functionality, and improve well-being for the child/adolescent and his/her close relationships, the measurement of health outcomes in this context is often limited to monitoring symptom reduction. This measurement often neglects a more comprehensive assessment of children/adolescents' health, which should encompass broad, positive and multidimensional outcomes, such as QL [18]. In fact, psychiatric symptom reduction and QL improvement are distinct dimensions of treatment for child/adolescent psychopathology because the latter may be achieved without necessarily implying the former [19]. That is, interventions that target psychiatric symptom reduction but overlook other factors related to pediatric QL may result in poor treatment outcomes [20]. Therefore, QL improvement should be assumed as a major goal of psychotherapeutic and psychiatric interventions in pediatric settings [21], encouraging greater sensitivity to patients' well-being and extending the outcome measures from mere psychopathology to the more overarching construct of QL [12].

In recent decades, QL has emerged as a primary health outcome in pediatric research and clinical practice as a means of facilitating patient-physician communication, improving patient and 
parent satisfaction, identifying hidden morbidities, and assisting in clinical decision making [22]. QL assessment in pedopsychiatric settings is not necessarily aimed at identifying causes of patients' mental disorders but instead focuses on children's and adolescents' broader functioning and the interference of disorders in their daily lives [14]. Generally, QL measurements can expand our knowledge of the impact of particular psychological disorders and can improve clinical and public healthcare services by integrating patients' perspectives into treatment plans and allocating resources according to the degree and complexity of QL impairments implied by different disorders [23]. Additionally, QL assessment may assume distinct relevance for the assessment and treatment of children and adolescents suffering from psychological disorders in several ways. First, it provides an overall assessment of functioning across multiple domains, thereby facilitating the adaptation of programs of care to the child's development and therapeutic progress. Second, it encourages children and adolescents to express their feelings regarding their own well-being and satisfaction with life to promote their autonomy and participation. Third, bearing in mind that symptom reduction does not necessarily mean improved day-to-day functioning, QL assessment broadens the scope of treatment progress monitoring in terms of patients' acquisition of new cognitive or social skills over a period of time and serves as an indicator of the impact of specific interventions on the child's or adolescent's environment $[11,24]$.

The core assumption of a developmental approach to QL assessment is that adult measures are inadequate for use in children and adolescents because of the level of abstraction required for decision making, the lack of developmental considerations, and the inclusion of areas that may be irrelevant or the exclusion of areas that may be important [8]. Moreover, school-aged children and adolescents have different cognitive abilities and face distinctive developmental tasks and challenges [7]. Therefore, an instrument is generally considered "developmentally appropriate" if the content of physical, psychological and social QL domains is related to the developmental contexts of children and adolescents and if its wording and format are adequate for children's and adolescents' language and cognitive skills [6]. Two methodological considerations have been consistently reiterated within a developmental approach to pediatric QL assessment: first, school-aged children and adolescents, despite experiencing age-specific tasks and contexts, share similar dimensions of the 
operationalization of their QL; second, self-reports and proxy reports may be assumed to be complementary, rather than mutually exclusive, sources of information [6-7, 9].

Although the most general domains of physical, psychological and social QL are developmentally universal, certain aspects of their content are age specific, such as the importance of play for children or dating for adolescents [25]. Nevertheless, the focus on age-universal QL markers, though likely to miss age-specific information, enables the comparison of information across childhood and adolescence [9], which is crucial for comparing or longitudinally examining pediatric health outcomes. In fact, one way to endorse a developmental approach in these situations is to approach age-group effects in statistical analyses [7] because it may be imprecise to study pediatric QL data covering wide age ranges without stratifying the results by age group [26]. For pedopsychiatric conditions, Dey and her colleagues [23] noted that children should be studied separately from adults because of age-specific issues for the former group, such as the distinctive progression of their physical and psychosocial development, their greater dependence upon adults, and different rates and clinical manifestations of mental disorders. A developmental approach to QL assessment asserts the same recommendation for studies involving school-aged children and adolescents to avoid the inaccuracy of assuming the former group to be "small adolescents" or the latter to merely be "grown up children" [7]. In fact, it has been suggested that the incorporation of QL assessments in the therapeutic process might increase in importance from childhood to adolescence because psychopathology may persist, and its impact on QL tends to increase with age [12].

Notwithstanding the fact that pediatric QL assessment should be child-centered and should employ self-reports whenever possible [5], some pediatric patients are not able to provide useful information on their QL, such as those who are too young, acutely ill or have severe disabilities. In these situations, the use of a proxy reporter, usually a parent, is the only way to obtain information on patients' QL [9, 27]. However, although many researchers use proxy ratings to assess QL in children/adolescents with psychological disorders even though it is advisable to employ self-reporting when the patient's cognitive abilities and particular diagnosis permit [23], the inclusion of multiple informants has also been strongly emphasized for QL assessment in this context. First, parent-child agreement is moderate, suggesting that parents may be better informants of their children's observable 
functioning, whereas children may provide unique information on their own inner experiences [13, 20]. Second, pediatric patients' perspectives may be flawed or distorted by psychopathological symptoms [28]. Third, the utilization of parents as proxy informants is a viable alternative for the assessment of their children's QL when a psychological disorder occurs at earlier ages [23].

To provide evidence-based guidelines for improving the developmental validity and methodological quality of current research trends, the aim of this systematic review was to ascertain the extent to which the aforementioned developmental approach has been applied in studies that conducted QL assessments in children and adolescents with psychological disorders. Accordingly, this review specifically aimed to analyze the consideration of three core methodological guidelines proposed by a developmental approach in studies conducted of the QL assessment of children/adolescents with psychological disorders: the utilization of developmentally appropriate instruments, the examination of age group specificities in school-aged children and adolescents, and the inclusion of self-reports and proxy reports in QL measurement.

\section{Methods}

\section{Search Strategy}

A systematic search was conducted by two reviewers (blind for review) to identify literature published between 1994 and May 2014 in three electronic databases: PubMed (U.S. National Library of Medicine), PsycINFO (name of host: OvidSP) and SocINDEX (name of host: EBSCOhost). The search strategy was defined by the combination of the following keywords: "quality of life", "mental disorder" or "psychological disorder" or "psychological problems" or "psychiatric disorders", and "child" or "adolescent" or "youth" or "pediatric". The detailed strategy used for searching the PsycINFO database is displayed in Table 1. This search strategy was used in all three databases, with minor modifications to fit the web interfaces. The Medical Subject Headings of the U.S. National Library of Medicine (MeSH terms) were used in the PubMed search.

\section{[Insert_Table_1]}

\section{Study Selection and Eligibility Criteria}

The selection of studies was conducted in two stages. Initially, the titles and abstracts of all retrieved records were screened to identify potentially relevant articles and to decide whether to 
obtain full texts. Subsequently, the selected full texts were assessed for eligibility by two reviewers (N. Silva and H. Moreira). Eligibility criteria were defined for types of studies, types of participants, and types of outcome measures [29].

Types of studies. Only empirical quantitative studies that were published in peer-reviewed journals between 1994 and May 2014 and that were written in the English language were considered. Duplicate or secondary publications on the same sample were excluded to avoid multiple-publication bias.

Types of participants. Studies were included if they assessed a sample of children/adolescents who were between 0 and 18 years of age with a clinical diagnosis of a mental disorder according to the Diagnostic and Statistical Manual of Mental Disorders (DSM) or the International Classification of Diseases (ICD) and who had no comorbidities with chronic physical conditions.

Types of outcome measures. The primary outcome for this systematic review was children/adolescents' self- or proxy-reported QL, conceptualized as a broad-ranging multidimensional construct covering the physical, psychological and social domains $[9,10]$. To assess pediatric QL, both generic and disease-specific instruments were considered as long as they covered the core domains of QL, not only the child's health status.

Full texts were excluded for the following reasons: (1) type of paper (e.g., letters to editors, reviews, etc.); (2) study design (e.g., qualitative research); (3) publication date prior to 1994; (4) absence of a sample of patients diagnosed with a mental disorder according to the DSM or ICD; (5) presence of comorbidities with chronic physical conditions; (6) inclusion of patients older than 19 years of age in the sample and no data reported for different age groups; (7) no data on pediatric QL as defined by the WHOQOL group; (8) inconsistent or insufficient information; and (9) duplicate publication.

\section{Data Extraction}

Following the Data Extraction Template for Cochrane Reviews [30] as a guide, two reviewers (N. Silva and H. Moreira) extracted the following information for each included study: (1) publication information, including authors and year of publication; (2) methods, including study design, methods 
and settings for the recruitment of participants, and inclusion/exclusion criteria for participation in the study; (3) participants, including sample size, country of origin, age (range, mean and standard deviation), and clinical characteristics (diagnosis and comorbidities with other health conditions); (4) outcomes, including methods and instruments used for assessing pediatric QL; and (5) statistical approach to age-related specificities. For studies reporting sociodemographic data separately for subgroups of participants (e.g., males and females or different diagnoses), data were combined into a single sample size, mean value and standard deviation [31]. Disagreements between the two reviewers were resolved by discussion to reach consensus.

\section{Results}

\section{Description of Studies}

Figure 1 presents the flow diagram summarizing the study selection process. The search identified 4438 articles containing the relevant terms. After removing the duplicates $(n=148), 4290$ articles were screened. Of these, 4085 (95\%) were excluded based on titles and abstracts. The remaining $205(5 \%)$ articles were examined, and only those that met the inclusion criteria were included in the systematic review $(n=66)$. Therefore, 139 articles were excluded based on the following exclusion criteria: the type of paper was not an empirical quantitative study $(n=4)$; the study design was not quantitative $(n=5)$; patients were not diagnosed with a mental disorder according to the DSM or the ICD $(n=29)$; the sample included patients with a comorbid chronic physical condition $(n=4)$; the sample included patients older than 19 years old, and no data were reported for different age groups $(n=41)$; no data were reported on pediatric QL $(n=26)$; the articles provided inconsistent or insufficient information $(n=23)$; and the same sample was used in more than one study $(n=7)$. The 66 articles meeting the inclusion criteria were reviewed, and the data pertaining to the research questions were extracted (see Figure 1).

\section{[Insert_Figure_1]}

As shown in Table 2, studies examining the QL of children with the following diagnoses of mental disorder were included: attention deficit hyperactivity disorder (ADHD; $n=27)$ [18; 32-57]; autism spectrum disorder $(n=10)$ [58-67]; Gilles de la Tourette syndrome or other tic disorder $(n=6)$ [68-73]; bipolar spectrum disorders $(n=5)$ [74-78]; enuresis $(n=3)$ [79-81]; separation anxiety 
disorder and anxiety disorders $(n=3)$ [82-84]; eating disorders $(n=2)$ [85-86]; major depressive disorder $(n=2)$ [87-88]; conduct disorder $(n=1)$ [89]; obsessive-compulsive disorder $(n=1)$ [24]; and learning disabilities $(n=1)$ [90]. Five studies included diverse diagnoses of a mental disorder [13$14,23,91-92]$.

The reviewed studies were conducted in several countries, including the US $(n=26)[24,32$ $33,37,43,45-47,51,53,59-60,63-64,67-68,72-74,76-78,86-87,89,91]$; Germany $(n=6)[40,44$, 48, 54, 79, 92]; Switzerland $(n=3)$ [23, 82, 84]; the Netherlands $(n=4)[13,38,52,66]$; Australia $(n$ =3) [14, 49-50]; Turkey $(n=3)[41,61,80]$; Brazil $(n=2)$ [39, 83]; Spain $(n=2)$ [36, 85]; Italy $(n=$ 2) [70, 71]; Taiwan $(n=2)$ [55-56]; Iran $(n=1)$ [42]; UK $(n=1)$ [69]; Norway $(n=1)$ [35]; Hungary $(n=1)$ [88]; France $(n=1)$ [58]; Canada $(n=1)$ [18]; Japan $(n=1)$ [81]; Greece $(n=1)$ [90]; and Mexico $(n=1)$ [57]. Four studies were conducted in two or more countries [34, 62, 65, 75]. Thirtytwo studies were cross-sectional $[13-14,18,23-24,36,39,42,50-51,53,55-56,59,61-65,68-70,72-$ $74,79-80,82,86,88,90-91]$, and 34 were longitudinal [32-35, 37-38, 40-41, 43-49, 52, 54, 57-58, 60, $66-67,71,75-78,81,83-85,87,89,92]$.

\section{[Insert_Table_2]}

\section{Assessment Instruments}

The majority of studies used age-appropriate instruments to assess children and adolescents' QL $(n=63 ; 95 \%)$. Only three (5\%) studies used instruments developed to assess QL in adult populations (SF-36 and EuroQoL-5D) [66, 85-86]. Among the studies that used age-appropriate instruments, the majority assessed multiple dimensions of QL $(n=52 ; 83 \%)[13-14,18,23-24,34-48$, $50-51,53-59,61-65,67-72,74-81,88,90-92]$, nine (14\%) studies only used the instruments' total scores or unidimensional scales [32-33, 49, 52, 60, 73, 84, 87, 89], and two (3\%) studies did not provide information about the instruments' dimensions used in the study [82-83].

\section{Age Group Analyses}

The studies included in the present review were analyzed in relation to their statistical approaches to the variable of pediatric patients' age. Age categories were defined according to the MeSH terms: preschoolers (2-5 years), children (6-12 years), and adolescents (13-18 years). As presented in Figure 2, no study included only preschoolers, 11 (17\%) studies included children 
exclusively [33, 35-36, 38-39, 52, 57-58, 63, 81, 92] and $4(6 \%)$ studies included adolescents exclusively $[37,71,75-76]$. The majority of studies comprised participants of more than one age group $(n=51 ; 77 \%)$ [13-14, 18, 23-24, 32, 34, 40-51, 53-56, 59-62, 64-70, 72-74, 77-80, 82-91]. Of these, 19 (29\%) did not report whether and/or how age was statistically treated [23, 41-44, 49, 53, 56, $60,64,67,69,73,82,84-86,89-90]$, and $32(48 \%)$ performed some sort of statistical analysis that involved the variable of age $[13-14,18,24,32,34,40,45-48,50-51,54-55,59,61-62,65-66,68,70$, $72,74,77-80,83,87-88,91]$.

\section{[Insert_Figure_2]}

Considering all studies in the present review (see Figure 3), approximately half of the studies did not report whether and/or how age was statistically treated $(n=34 ; 52 \%)[23,33,35-39,41-44$, $49,52-53,56-58,60,63-64,67,69,71,73,75-76,81-82,84-86,89-90,92]$. The remaining studies analyzed the correlations between age and QL $(n=4 ; 6 \%)[32,74,79-80]$, performed separate analyses for different age groups $(n=4 ; 6 \%)[34,40,48,77]$, compared QL scores between age groups $(n=6 ; 9 \%)[13,24,61-62,72,87]$, introduced age as a covariate in comparison analyses $(n=$ $8 ; 12 \%)[45,47,51,54,59,65,70,83]$, or analyzed age as a predictor in regression analyses $(n=10$; $15 \%)[14,18,46,50,55,66,68,78,88,91]$.

\section{[Insert_Figure_3]}

\section{Self versus Proxy Reports}

As presented in Figure 4, the QL of children was self-reported in 14 (21\%) studies [37, 39, $45,51,56-57,69-71,80,83,85-87]$ and assessed through parents' proxy reports in 29 (44\%) studies $[14,18,32-33,36,43,46-47,49-50,52,54-55,58-59,60-63,65,67-68,74-77,89,91-92]$. In 23 (35\%) studies, self-reports and proxy reports were both used to assess children's QL [13, 23-24, 34$35,38,40-42,44,48,53,64,66,72-73,78-79,81-82,84,88,90]$.

[Insert_Figure_4]

\section{Discussion}

This review aimed to operationalize a developmental approach to QL assessment in children and adolescents with psychological disorders while systematically examining the extent to which such methodological guidelines were effectively applied in the context of pedopsychiatric QL research. 
This review thus represents an original contribution to the delineation of a clear-cut methodological framework that seeks to enhance the developmental appropriateness of QL assessments for children and adolescents suffering from mental disorders by proposing three core operational procedures: the administration of developmentally appropriate instruments; the study of childhood and adolescence as independent, though consecutive, age groups; and the simultaneous utilization of self-reports and proxy reports. Following a selection process of studies conducted over the last twenty years on the QL of children and adolescents with psychological disorders, the systematic review of 66 studies allowed us to obtain a straightforward picture of recent research trends to substantiate the aforementioned developmental approach for this specific pediatric population. First, the large majority of studies adopted developmentally appropriate instruments in their research assessment protocols. Second, nearly one-third of the examined studies did not perform age analyses even though the age range of their participants encompassed more than one age group. Of the remaining half of the studies that performed such analyses, only a modest proportion distinguished between the age groups of schoolaged children and/or adolescents. Third, despite the fact that most studies exclusively employed proxy reports (nearly double the amount of those that used self-reports only), approximately one-third of them used self-reports and proxy reports simultaneously. These results generally portray a positive trend in applying a developmental approach to QL measurement in children and adolescents with mental disorders and, most importantly, support the identification of areas for further improvement of this methodological challenge in pedopsychiatric research.

The acknowledgement of developmental specificities in pediatric QL assessment is evident in the utilization of developmentally appropriate instruments by the large majority of the reviewed studies assessing the QL of children and adolescents with mental disorders. Although QL for people across the life span should be conceptualized in terms of similar overall domains (i.e., physical, psychological and social), developmental considerations must be taken into account when selecting the specific aspects to integrate in a QL domain [93]. Given that a number of QL instruments with sound psychometric properties have been developed over recent years and are now available in a variety of languages, it is no longer acceptable to utilize adult QL measures, such as the Medical Outcomes Study (MOS)-SF-36 or the EuroQoL-5D, to conduct these assessments in pediatric 
populations. The PedsQL [94], KIDSCREEN [95], and KINDL questionnaires [96] are widespread measures that, in addition to their well-established developmental adequacy and sound psychometric properties, may facilitate cross-cultural pediatric QL studies for pediatric patients with chronic physical conditions [97], which are lacking for pedopsychiatric patients. Nevertheless, it is interesting that in a 1993 paper, the WHO stated that children's QL instruments should "be age-related or at least developmentally appropriate" (p. 3), thus revealing the subtlety of a distinction between age group specificities from common QL markers across childhood and adolescence. It seems crucial to accept that age-specific and common markers are both relevant for pediatric QL assessments in the sense that they allow greater developmental sensitivity paired with the possibility of conducting longitudinal or between-age-group comparisons, respectively. To resolve this apparent dilemma, two recommendations are advanced. One recommendation is to use different age versions of the same instrument [9], as is the case for the three forms of the KINDL questionnaires [96]: KINDL-Kiddy (47 years), KINDL-Kid (8-12 years) and KINDL-Kiddo (13-16 years). Another option is to complement QL measurements based on common markers with supplemental assessments that account for the most age-specific aspects [98]. Although the latter suggestion may be fairly easy to implement in clinical practice (by gathering additional information from clinical interviews, for instance), for more formal assessments, such as those required in research, the development of age-specific modules may be pertinent. In fact, although the importance of disease-specific modules has been amply acknowledged in the context of health-related QL assessments for physical conditions [99], the development of age-specific modules for school-aged children and adolescents could represent a practical way of fully endorsing a developmental approach to QL measurement by simultaneously focusing on common QL markers and age-specific aspects across both age groups. Although this has not been the dominant trend in pediatric QL research, the fact that psychopathology tends to persist from childhood into adolescence [3] may motivate the adoption and refinement of this procedure in pedopsychiatric settings, where age-specific abilities, contexts and tasks are decisive for effectively planning and implementing interventions.

Despite the fact that age is likely to be a primary developmental variable that must be considered in pediatric psychosocial research [100], nearly one-third of the studies included in this 
review did not analyze the influence of age on QL outcomes and did not present results stratified by age groups. Of the remaining studies that performed specific age analyses (nearly half of the studies reviewed), there was significant variability in the ways this variable was statistically approached, including age as a covariate, correlate or predictor; QL comparisons between age groups; and separate analyses for different age groups. In this context, statistical analyses that differentiate age groups seem preferable for two main reasons. First, they are especially useful to detect differences and similarities in terms of both QL outcomes and QL predictors that could otherwise be masked or overlooked across two subgroups of pediatric patients. Second, the age clustering of school-aged children and adolescents is especially desirable to inform clinical practice because it provides a practical way of conveying knowledge that is not necessarily invariant across subgroups of pedopsychiatric patients. These subgroups pose different challenges and require distinct approaches in a variety of assessment and intervention situations in regular clinical routines. The fact that age was statistically treated as a covariate in some of the studies reviewed, although pertinent to controlling for that specific effect in variance analyses, does not provide insight into the role of age in determining QL outcomes. Likewise, the analysis of age as a correlate or predictor, though useful for examining or even discriminating its effects on QL outcomes, does not facilitate a practical translation of empirical research results into pedopsychiatric clinical practice, where age groups may be used to differentiate screening routines, the allocation of resources and service delivery. In fact, a developmental approach to QL assessment in this context would call for age-group analyses even at the level of psychometric examinations [98], which should be preliminary to any other analysis. This is particularly noteworthy not only because common QL dimensions may encompass different features in the daily life experiences of school-aged children and adolescents (e.g., family relationships, school functioning) [93] but also because the psychometric quality of broadband QL measures may differ across the two age groups [98]. However, the definition of these age groups is not straightforward. Although studies generally endorse the idea that any school-aged child can self-report his or her health [101] and despite evidence of reliable QL self-reports from children five years and older [102], in the context of the present review, it is suggested that school-aged children and adolescents with mental disorders can be clustered within the age groups of 8-12 years and 13-18 years old, respectively, as a harmonized 
guideline for research. This guideline is in agreement with the methodological options of previous world-renowned pediatric QL projects, such as KIDSCREEN [103], PedsQL [94] and DISABKIDS [97].

The WHO recommendation of employing subjective self-reports whenever possible in the context of children's QL measurement [5] appears fairly established in the reviewed literature on the QL of children and adolescents with psychological disorders. Slightly more than half of the studies obtained self-reports, and the remaining were exclusively based on proxy reports, usually obtained from parents. However, the simultaneous utilization of self-reports and proxy reports was adopted in only approximately one-third of the studies under review. This complementary use of self-reports and proxy reports is not a minor issue for the operationalization of a developmental approach to pedopsychiatric QL assessment. Although parents' reports and their children's QL reports are valid, they cannot effectively supplant each other [104]. From this perspective, the complexity and costs related to this methodological option are surpassed by a number of advantages and applications. First, although children' and adolescents' perceptions are vital to substantiate patient-centered pediatric healthcare and although these perceptions are inevitably (even if indirectly) targeted in psychological or psychiatric interventions, parents have the primary responsibility in pediatric clinical decision making, which is likely to be strongly influenced by their own perceptions of their child's functioning and well-being. Second, parents who have children with chronic conditions tend to underestimate their children's QL [27]. Hence, an exclusive focus on parents' reports may hinder the implementation of an empowering, strength-based approach to children and adolescents with mental disorders by neglecting their resiliency and their abilities to fulfill their potential [16]. Third, the replication of analyses crossing self- and proxy-reported data on pediatric QL outcomes contributes to improving the clinical validity of the observed results $[98,105]$. Fourth, not only does parent-child concordance tend to be moderate in pediatric QL assessments, but, perhaps most importantly, the strength and direction of this (dis)agreement may also be linked to modifiable family factors [106] that can be targeted in the assessments performed and the interventions designed for pedopsychiatric patients. Taking this rationale into account, a developmental approach would argue for the complementary use of self-reports and proxy reports in the QL assessment of children and adolescents 
with psychological disorders, which goes beyond the selective use of either source of information.

Despite its relative recency, the QL assessment of children and adolescents with mental disorders has been progressing steadily, as illustrated by the number of studies included in the present review. The challenge in research is now twofold: on the one hand, to improve the quality of research designs by systematically incorporating the aforementioned guidelines for the operationalization of a developmental approach to pedopsychiatric QL assessment; on the other hand, to move from outcome descriptions, which are important to characterize pedopsychiatric populations and their sub-groups, to outcome predictions, which enable the identification of modifiable variables and targeted links to promote the QL of children and adolescents with mental disorders. Some evidence has identified stressful life events, low self-esteem, poor social skills and poor social support as predictors of impaired QL for children and adolescents suffering from psychological disorders [13]. Nevertheless, this work could be expanded through mediation analyses that permit the development of theory from merely descriptive to a more functional understanding of the relationships between variables [107]. Additionally, the examination of mediation models could be strengthened by the assessment of their (in)variance across age groups, the inclusion of multiple informants, and the integration of developmentally appropriate and adequately validated measures. Moreover, for the adequate development and psychometric validation of QoL instruments, statistical methods such as Item Response Theory (REF) or Rash Analysis (REF) are currently recommended / should be considered. Moreover, the role of parents in pedopsychiatric QL research may go beyond their inclusion as proxies in obtaining child-related information. Given that pediatric clinical practice is generally expected to work with at least two patients simultaneously, a child and a parent [108], the incorporation of a parent-child dyadic perspective with the simultaneous assessment of parents' and their children's QL [109] could broaden the focus of clinical theory, case formulation and intervention. In fact, many psychotherapeutic interventions targeting children's and adolescents' psychological disorders often imply some degree of parental involvement (e.g., behavior reinforcement schedules, improvement of family routines and communication patterns, mastery and social activity monitoring, reduction of self-criticism). Hence, it is relevant to apply a parent-child perspective to foster family pediatrics in the context of child and adolescent psychopathology and 
psychotherapy. Finally, although QL measures have been frequently used to describe disease impact or treatment effects, they may also be assumed to be targets for psychological intervention or mental health promotion [110]. For instance, the term "QL therapy" has been coined to describe a psychotherapeutic model that, instead of diagnosing and targeting psychopathological symptoms, focuses its action on the patient's QL profile as a means of mapping interventions [111]. Because children and adolescents with mental disorders and their families face daily life problems that go beyond the symptoms that characterize their disorders [14], it makes sense to broaden the focus of pedopsychiatric assessment and intervention to encompass QL measures because an exclusive focus on negative outcomes and dimensions can only provide an incomplete picture [112]. Therefore, the assessment of the QL of children and adolescents with psychological disorders may contribute to the identification of relevant contexts, resources and areas of good functioning that may foster the effectiveness of intervention processes by identifying what is effective and should be used as well as what is ineffective and requires improvement.

\section{Expert commentary:}

Despite its relative recency, the measurement of the QL of children and adolescents with psychological disorders has gained increased attention in research. The quality of this research is largely dependent on the endorsement of a developmental approach to QL assessment. This developmental approach may be methodologically operationalized through the administration of developmentally appropriate instruments, the acknowledgement of age group specificities and the inclusion of both self-reports and proxy reports. Although most empirical studies conducted over the last decades have employed developmentally appropriate measures, a significant proportion have not attended to age group specificities and have only included either self-reports or proxy reports on children's and adolescents' QL. The incorporation of such guidelines into pedopsychiatric QL research is likely to result in increased methodological complexity as well as greater developmental validity of the observed results and their implications. These best practices in research can systematically inform pedopsychiatric clinical practice by broadening the scope of assessments and interventions and promoting their effectiveness. 


\section{Five-year view:}

The importance of assessing the QL of children and adolescents with psychological disorders will increase in both research and clinical settings in the coming years. Likewise, the methodological complexity of research designs will increase toward greater developmental sensitivity, and the psychotherapeutic applications of QL assessments will receive renewed interest for improving the spectrum and quality of treatment outcomes in pedopsychiatric settings. Although the utilization of developmentally appropriate measures seems to be rather established in the field, interest in assessing common QL markers across childhood and adolescence paired with the need to complement them with QL aspects that are specifically related to either age group will likely result in greater methodological complexity and greater strength of research designs. It is also expected that greater attention will be directed toward the QL of parents who have children with mental disorders to substantiate a dyadic parent-child perspective that will contribute to the refinement of a developmental approach to pedopsychiatric QL assessment and intervention processes. The field has now reached a stage that requires a research movement from outcome descriptions to outcome predictions. Thus, it will be vital to examine mediation models linking pedopsychiatric QL outcomes with modifiable variables and mechanisms, which can be targeted in interventions aimed at promoting the QL of children and adolescents with psychological disorders.

\section{Key issues:}

- School-aged children (8-12 years) and adolescents (13-18 years) pose unique developmental challenges to the assessment of their quality of life (QL).

- Children and adolescents with psychological disorders have significant QL impairments that go beyond their psychopathological symptoms.

- QL measurements should be integrated into pedopsychiatric assessments and intervention processes along with psychopathological measures.

- A developmental approach to QL assessment implies the administration of developmentally appropriate instruments, the acknowledgement of age group specificities and the inclusion of both 
self-reports and proxy reports.

- School-aged children and adolescents with psychological disorders share common QL markers, but their age group specificities should not be neglected in QL measurements.

- Self and proxy sources for pedopsychiatric QL assessment should be assumed to be complementary to each other rather than mutually exclusive.

- QL measures broaden the scope of pedopsychiatric assessments and are thus likely to improve the effectiveness of intervention processes.

- QL assessments may facilitate case formulation by mapping individual and contextual aspects that may act as predisposing, precipitating and/or perpetuating factors for child and adolescent psychopathology.

- Developmentally appropriate QL assessments are practical means of empowering children and adolescents with mental disorders as well as their parents by actively involving them in a strengthbased approach to psychotherapeutic processes. 


\section{References}

1. Drotar D (ed.). Measuring health-related quality of life in children and adolescents: Implications for research and practice. Lawrence Erlbaum Associates, Hillsdale, NJ, 1998

2. Ramchandani P. Prevalence of childhood psychiatric disorders may be underestimated. Evid Based Ment Health. 2004;7(2):59. doi:10.1136/ebmh.7.2.59

3. Costello EJ, Mustillo S, Erkanli A, et al. Prevalence and development of psychiatric disorders in childhood and adolescence. Arch Gen Psychiatry. 2003;60(8):837-844. doi:10.1001/archpsyc.60.8.837

4. Cicchetti D. Development and psychopathology. In: Cicchetti D, Cohen DJ (eds.), Developmental psychopathology. Volume 1: Theory and method (pp. 1-23). New York, NY: Wiley, 2006

5. World Health Organization. Measurement of quality of life in children: report of WHO/IACAPAP working party. London, UK, 1993

6. Bruil J, Detmar SB. Measuring health-related quality of life in children: Difficulties and challenges. Expert Rev Pharmacoeconomics Outcomes Res. 2005;5(5):511-514. doi:10.1586/14737167.5.5.511

7. Carona C, Crespo C, Silva N, et al. Examining a developmental approach to health-related quality of life assessment: Psychometric analysis of DISABKIDS generic module in a Portuguese sample. Vulnerable Child Youth Stud. 2013;8(3):243-257. doi:10.1080/17450128.2012.736647

8. Spieth LE, Harris CV. Assessment of health-related quality of life in children and adolescents: An integrative review. J Pediatr Psychol. 1996;21(2):175-193. doi:10.1093/jpepsy/21.2.175

9. Wallander JL, Schmitt M, Koot HM. Quality of life measurement in children and adolescents: Issues, instruments, and applications. J Clin Psychol. 2001;57(4):571-585. doi:10.1002/jclp.1029 **A concise, clear-cut synthesis of methodological challenges in QL assessment related to the development of children and adolescents.

10. The WHOQOL Group. Study protocol for the World Health Organization project to develop a Quality of Life assessment instrument (WHOQOL). Qual Life Res. 1993;2(2):153-159. doi:10.1007/BF00435734

11. White-Koning M, Gayral-Taminh M, Lauwers-Cancès V, et al. Assessing the quality of life of children with mental disorders using a computer-based self-reported generic instrument (KidIQoL) - Quality of life of children with mental disorders. OJPsych. 2011;1(1):8-14. doi:10.4236/ojpsych.2011.11002

12. Weitkamp K, Daniels JK, Romer G, Wiegand-Grefe S. Health-related quality of life of children and adolescents with mental disorders. Health Qual Life Outcomes. 2013;11:129. doi:10.1186/1477-7525-11-129

13. Bastiaansen D, Koot HM, Ferdinand RF, Verhulst FC. Quality of life in children with psychiatric disorders: Self-, parent, and clinician report. J Am Acad Child Adolesc Psychiatry. 2004;43:221230. doi:10.1097/00004583-200402000-00019

*A well-designed study focusing the importance of multiple informants in QL assessment of children and adolescents with psychological disorders.

14. Sawyer MG, Whaites L, Rey JM, et al., Health-related quality of life of children and adolescents with mental disorders. J Am Acad Child Adolesc Psychiatry. 2002;41:530-537. doi:10.1097/00004583-200205000-00010

15. World Health Organization (WHO). The ICD-10 classification of mental and behavioural disorders. Clinical descriptions and diagnostic guidelines. WHO, Geneva, 1992

16. Patel V, Flisher AJ, Hetrick S, McGorry P. Mental health of young people: a global public-health 
challenge. The Lancet. 2007;369(9569):1302-1313. doi:10.1016/S0140-6736(07)60368-7

17. Prince M, Patel V, Saxena S, et al. No health without mental health. The Lancet. 2007;370(9590):859-877. doi:10.1016/S0140-6736(07)61238-0

18. Klassen AF, Miller A, Fine S. Health-related quality of life in children and adolescents who have a diagnosis of attention-deficit/hyperactivity disorder. Pediatrics. 2004;114(5):e541-e547. doi:10.1542/peds.2004-0844

19. Bastiaansen D, Koot HM, Ferdinand RF. Psychopathology in children: Improvement of quality of life without psychiatric symptom reduction? Eur Child Adolesc Psychiatry. 2005;14:364-370. doi:10.1007/s00787-005-0481-8

20. Bastiaansen D, Koot HM, Ferdinand RF. Determinants of quality of life in children with psychiatric disorders. Qual Life Res. 2005;14(6):1599-1612. doi:10.1007/s11136-004-7711-2

21. Schmeck K, Poustka F. Quality of life and child psychiatric disorders. In: Katschnig H, Freeman H, Sartorius N (eds.), Quality of life in mental disorders (pp. 179-191). Chichester: Wiley, 1997

22. Varni JW, Burwinkle TM, Lane MM. Health-related quality of life measurement in pediatric clinical practice: An appraisal and precept for future research and application. Health Qual Life Outcomes.2005;3:34. doi:10.1186/1477-7525-3-34

**A sharp synthesis on the rationale for QL assessment in pediatric populations, as well as on the barriers for its effective implementation.

23. Dey M, Mohler-Kuo M, Landolt MA. Health-related quality of life among children with mental health problems: A population-based approach. Health Qual Life Outcomes. 2012;10:73. doi:10.1186/1477-7525-10-73

24. Lack CW, Storch EA, Keeley ML, et al. Quality of life in children and adolescents with obsessive-compulsive disorder: Base rates, parent-child agreement, and clinical correlates. Soc Psychiatry Psychiatr Epidemiol. 2009;44(11):935-942. doi:10.1007/s00127-009-0013-9

25. Carona C, Silva N, Moreira H, et al. Does the small fit them all? The utility of Disabkids-10 Index for the assessment of pediatric health-related quality of life across age-groups, genders, and informants. J Child Health Care. Forthcoming 2014. doi: 10.1177/1367493514522867

26. Gerharz EW, Eiser C, Woodhouse CR. Current approaches to assessing the quality of life in children and adolescents. BJU Int. 2003;91(2):150-154. doi:10.1046/j.1464-410X.2003.04001.x

27. White-Koning M, Arnaud C, Dickinson HO, et al. Determinants of child-parent agreement in quality of life reports: A European study of children with cerebral palsy. Pediatrics. 2007;120(4):e804-e814. doi:10.1542/peds.2006-3272

28. Sainfort F, Becker M, Diamond R. Judgments of quality of life of individuals with severe mental disorders: Patient self-report versus provider perspectives. Am J Psychiatry. 1996;153(4):497502.

29. Liberati A, Altman DG, Tetzlaff J, et al. The PRISMA statement for reporting systematic reviews and meta-analyses of studies that evaluate healthcare interventions: Explanation and elaboration. BMJ. 2009;339:b2700. doi:10.1136/bmj.b2700.

30. Cochrane Consumers and Communication Review Group. Data Extraction Template for Cochrane Reviews, version 1.5.0 [Internet]. Melbourne: La Trobe University; 2013 Feb. Available from: http://cccrg.cochrane.org/sites/cccrg.cochrane.org/files/uploads/DET_2013_0.doc

31. Higgins JPT, Green S. (Eds.). Cochrane handbook for systematic reviews of interventions. West Sussex, UK: John Wiley \& Sons Ltd., 2008.

32. Bastiaens L. Both atomoxetine and stimulants improve quality of life in an ADHD population treated in a community clinic. Psychiatr Q. 2008;79(2):133-137. doi:10.1007/s11126-008-9070-6

33. Bastiaens L. Improvement in global psychopathology increases quality of life during treatment of ADHD with atomoxetine or stimulants. Psychiatr Q. 2011;82(4):303-308. doi:10.1007/s11126- 
011-9172-4

34. Becker A, Roessner V, Breuer D, et al. Relationship between quality of life and psychopathological profile: Data from an observational study in children with ADHD. Eur Child Adolesc Psychiatry. 2011;20(S2):267-275. doi:10.1007/s00787-011-0204-2

35. Cuypers K, De Ridder K, Strandheim A. The effect of therapeutic horseback riding on 5 children with attention deficit hyperactivity disorder: A pilot study. J Altern Complement Med. 2011;17(10):901-908. doi:10.1089/acm.2010.0547

36. Escobar R, Soutullo CA, Hervas A, et al. Worse quality of life for children with newly diagnosed attention-deficit/hyperactivity disorder, compared with asthmatic and healthy children. Pediatrics. 2005;116(3):e364-e369. doi:10.1542/peds.2005-0386

37. Findling RL, Cutler AJ, Saylor K, et al. A long-term open-label safety and effectiveness trial of lisdexamfetamine dimesylate in adolescents with attention-deficit/hyperactivity disorder. $J$ Child Adolesc Psychopharmacol. 2013;23(1):11-21. doi:10.1089/cap.2011.0088

38. Flapper BC, Schoemaker MM. Effects of methylphenidate on quality of life in children with both developmental coordination disorder and ADHD. Dev Med Child Neurol. 2008;50(4):294-299. doi:10.1111/j.1469-8749.2008.02039.x

39. Goulardins JB, Marques JC, Casella EB. Quality of life and psychomotor profile of children with attention deficit hyperactivity disorder (ADHD). Arq Neuropsiquiatr. 2011;69(4):630-635. doi:10.1590/S0004-282X2011000500011

40. Görtz-Dorten A, Breuer D, Hautmann C, et al. What contributes to patient and parent satisfaction with medication in the treatment of children with ADHD? A report on the development of a new rating scale. Eur Child Adolesc Psychiatry. 2011;20(S2):297-307. doi:10.1007/s00787-011-0207$\mathrm{z}$

41. Gürkan K, Bilgiç A, Türkoglu S, et al. Depression, anxiety and obsessive-compulsive symptoms and quality of life in children with attention-deficit hyperactivity disorder (ADHD) during threemonth methylphenidate treatment. J Psychopharmacol. 2010;24(12):1810-1818. doi:10.1177/0269881109348172

42. Jafari P, Ghanizadeh A, Akhondzadeh S, Mohammadi MR. Health-related quality of life of Iranian children with attention deficit/hyperactivity disorder. Qual Life Res. 2011;20(1):31-36. doi:10.1007/s11136-010-9722-5

43. Newcorn JH, Spencer TJ, Biederman J, et al. Atomoxetine treatment in children and adolescents with attention-deficit/hyperactivity disorder and comorbid oppositional defiant disorder. $\mathrm{J} \mathrm{Am}$ Acad Child Adolesc Psychiatry. 2005;44(3):240-248. doi:10.1097/00004583-200503000-00008

44. Niederkirchner K, Slawik L, Wermelskirchen D, et al. Transitioning to OROS ${ }^{\circledR}$ methylphenidate from atomoxetine is effective in children and adolescents with ADHD. Expert Rev Neurother. 2011;11(4):499-508. doi:10.1586/ern.11.18

45. Patrick DL, Edwards TC, Topolski TD. Adolescent quality of life, part II: Initial validation of a new instrument. $J$ Adolesc. 2002;25(3):287-300. doi:10.1006/jado.2002.0471

46. Perwien AR, Kratochvil CJ, Faries DE, et al. Atomoxetine treatment in children and adolescents with attention-deficit hyperactivity disorder: What are the long-term health-related quality-of-life outcomes? J Child Adolesc Psychopharmacol. 2006;16(6):713-724.

47. Rentz AM, Matza LS, Secnik K, et al. Psychometric validation of the child health questionnaire (CHQ) in a sample of children and adolescents with attention-deficit/hyperactivity disorder. Qual Life Res. 2005;14(3):719-734. doi:10.1007/s11136-004-0832-9

48. Rothenberger A, Becker A, Breuer D, Döpfner M. An observational study of once-daily modified-release methylphenidate in ADHD: Quality of life, satisfaction with treatment and adherence. Eur Child Adolesc Psychiatry. 2011;20(S2):257-265. doi:10.1007/s00787-011-0203-3

49. Sciberras E, Fulton M, Efron D, et al. Managing sleep problems in school aged children with 
ADHD: A pilot randomised controlled trial. Sleep Med. 2011;12(9):932-935. doi:10.1016/j.sleep.2011.02.006

50. Sung V, Hiscock H, Sciberras E, Efron D. Sleep problems in children with attentiondeficit/hyperactivity disorder: Prevalence and the effect on the child and family. Arch Pediatr Adolesc Med. 2008;162(4):336-342. doi:10.1001/archpedi.162.4.336

51. Topolski TD, Edwards TC, Patrick DL, et al. Quality of life of adolescent males with attentiondeficit hyperactivity disorder. J Atten Disord. 2004;7(3):163-173.

52. Van der Heijden KB, Smits MG, Van Someren EJ, et al. Effect of melatonin on sleep, behavior, and cognition in ADHD and chronic sleep-onset insomnia. J Am Acad Child Adolesc Psychiatry. 2007;46(2):233-241. doi:10.1097/01.chi.0000246055.76167.0d

53. Varni JW, Burwinkle TM. The PedsQL as a patient-reported outcome in children and adolescents with Attention-Deficit/Hyperactivity Disorder: A population-based study. Health Qual Life Outcomes. 2006;4:26. doi:10.1186/1477-7525-4-26

54. Wehmeier PM, Schacht A, Dittmann RW, et al. Effect of atomoxetine on quality of life and family burden: Results from a randomized, placebo-controlled, double-blind study in children and adolescents with ADHD and comorbid oppositional defiant or conduct disorder. Qual Life Res. 2011;20(5):691-702. doi:10.1007/s11136-010-9803-5

55. Yang P, Hsu HY, Chiou SS, Chao MC. Health-related quality of life in methylphenidate-treated children with attention-deficit-hyperactivity disorder: results from a Taiwanese sample. Aust NZ J Psychiatry. 2007;41(12):998-1004

56. Yang PC, Lung FW, Chiou SS, et al. Quality of life of methylphenidate treatment-responsive adolescents with attention-deficit/hyperactivity disorder. Kaohsiung J Med Sci. 2012;28(5):279284. doi:10.1016/j.kjms.2011.10.013

57. Zambrano-Sánchez E, Martínez-Cortés JA, del Río-Carlos Y, et al. Low quality of life scores in school children with attention deficit-hyperactivity disorder related to anxiety. Arq Neuropsiquiatr. 2012;70(3):180-184. doi:10.1590/S0004-282X2012000300005

58. Baghdadli A, Brisot J, Henry V, et al. Social skills improvement in children with highfunctioning autism: A pilot randomized controlled trial. Eur Child Adolesc Psychiatry. 2013;22(7):433-442. doi:10.1007/s00787-013-0388-8

59. Delahaye J, Kovacs E, Sikora D, et al. The relationship between health-related quality of life and sleep problems in children with Autism Spectrum Disorders. Res Autism Spect Dis. 2014;8(3):292-303. doi:10.1016/j.rasd.2013.12.015

60. Kern JK, Fletcher CL, Garver CR, et al. Prospective trial of equine-assisted activities in autism spectrum disorder. Altern Ther Health Med. 2011;17(3):14-20.

61. Kose S, Erermis S, Ozturk O, et al. Health related quality of life in children with Autism Spectrum Disorders: The clinical and demographic related factors in Turkey. Res Autism Spect Dis. 2013;7(2):213-220. doi:10.1016/j.rasd.2012.09.009

62. Kuhlthau K, Orlich F, Hall TA, et al. Health-related quality of life in children with autism spectrum disorders: Results from the autism treatment network. J Autism Dev Disord. 2010;40(6):721-729. doi:10.1007/s10803-009-0921-2

63. Limbers CA, Heffer RW, Varni JW. Health-related quality of life and cognitive functioning from the perspective of parents of school-aged children with Asperger's syndrome utilizing the PedsQLTM. J Autism Dev Disord. 2009;39(11):1529-1541. doi:10.1007/s10803-009-0777-5

64. Sheldrick RC, Neger EN, Shipman D, Perrin EC. Quality of life of adolescents with autism spectrum disorders: Concordance among adolescents' self-reports, parents' reports, and parents' proxy reports. Qual Life Res. 2012;21(1):53-57. doi:10.1007/s11136-011-9916-5

65. Sikora DM, Vora P, Coury DL, Rosenberg D. Attention-deficit/hyperactivity disorder symptoms, adaptive functioning, and quality of life in children with autism spectrum disorder. Pediatrics. 
2012;130(S2):91-97. doi:10.1542/peds.2012-0900G

66. van Steensel FJ, Bögels SM, Dirksen CD. Anxiety and quality of life: clinically anxious children with and without autism spectrum disorders compared. J Clin Child Adolesc Psychol. 2012;41(6):731-738. doi:10.1080/15374416.2012.698725

67. Varni JW, Handen BL, Corey-Lisle PK, et al. Effect of aripiprazole 2 to $15 \mathrm{mg} / \mathrm{d}$ on healthrelated quality of life in the treatment of irritability associated with autistic disorder in children: A post hoc analysis of two controlled trials. Clin Ther. 2012;34(4):980-992. doi:10.1016/j.clinthera.2012.02.023

68. Bernard BA, Stebbins GT, Siegel S, et al. Determinants of quality of life in children with Gilles de la Tourette syndrome. Mov Disord. 2009;24(7):1070-1073. doi:10.1002/mds.22487

69. Cutler D, Murphy T, Gilmour J, Heyman I. The quality of life of young people with Tourette syndrome. Child Care Health Dev. 2009;35(4):496-504. doi:10.1111/j.1365-2214.2009.00983.x

70. Eddy CM, Rizzo R, Gulisano M, et al. Quality of life in young people with Tourette syndrome: A controlled study. J Neurol. 2011;258(2):291-301. doi:10.1007/s00415-010-5754-6

71. Rizzo R, Gulisano M, Calì PV, Curatolo P. Long term clinical course of Tourette syndrome. Brain Dev. 2012;34(8):667-673. doi:10.1016/j.braindev.2011.11.006

72. Storch EA, Merlo LJ, Lack C, et al. Quality of life in youth with Tourette's syndrome and chronic tic disorder. J Clin Child Adolesc Psychol. 2007;36(2):217-227. doi:10.1080/15374410701279545

73. Zinner SH, Conelea CA, Glew GM, et al. Peer victimization in youth with Tourette syndrome and other chronic tic disorders. Child Psychiatry Hum Dev. 2012;43(1):124-136. doi:10.1007/s10578-011-0249-y

74. Algorta GP, Youngstrom EA, Frazier TW, et al. Suicidality in pediatric bipolar disorder: predictor or outcome of family processes and mixed mood presentation? Bipolar Disord. 2011;13(1):76-86. doi:10.1111/j.1399-5618.2010.00886.x

75. Olsen BT, Ganocy SJ, Bitter SM, et al. Health-related quality of life as measured by the child health questionnaire in adolescents with bipolar disorder treated with olanzapine. Compr Psychiatry. 2012;53(7):1000-1005. doi:10.1016/j.comppsych.2012.03.010

76. Rademacher J, DelBello MP, Adler C, et al. Health-related quality of life in adolescents with bipolar I disorder. J Child Adolesc Psychopharmacol. 2007;17(1):97-103. doi:10.1089/cap.2006.0049

77. Stewart M, DelBello MP, Versavel M, Keller D. Psychosocial functioning and health-related quality of life in children and adolescents treated with open-label ziprasidone for bipolar mania, schizophrenia, or schizoaffective disorder. J Child Adolesc Psychopharmacol. 2009;19(6):635640. doi:10.1089/cap.2008.0158 doi:10.1016/j.jad.2013.05.039

78. Van Meter AR, Henry DB, West AE. What goes up must come down: the burden of bipolar depression in youth. J Affect Disord. 2013;150(3):1048-1054.

79. Bachmann C, Ackmann C, Janhsen E, et al. Clinical evaluation of the short-form pediatric enuresis module to assess quality of life. Neurourol Urodyn. 2010;29(8):1397-1402. doi:10.1002/nau.20896

80. Ertan P, Yilmaz O, Caglayan M, et al. Relationship of sleep quality and quality of life in children with monosymptomatic enuresis. Child Care Health Dev. 2009;35(4):469-74. doi:10.1111/j.1365-2214.2009.00940.x

81. Naitoh Y, Kawauchi A, Soh J, et al. Health related quality of life for monosymptomatic enuretic children and their mothers. J Urol. 2012;188(5):1910-1914. doi:10.1016/j.juro.2012.07.012

82. Allen JL, Blatter-Meunier J, Ursprung A, Schneider S. The Separation Anxiety Daily Diary: Child version: Feasibility and psychometric properties. Child Psychiatry Hum Dev. 
2010;41(6):649-662. doi:10.1007/s10578-010-0194-1

83. de Souza MA, Salum GA, Jarros RB, et al. Cognitive-behavioral group therapy for youths with anxiety disorders in the community: Effectiveness in low and middle income countries. Behav Cogn Psychother. 2013;41(3):255-264. doi:10.1017/S1352465813000015

84. Schneider S, Blatter-Meunier J, Herren C, et al. Disorder-specific cognitive-behavioral therapy for separation anxiety disorder in young children: A randomized waiting-list-controlled trial. Psychother Psychosom. 2011;80(4):206-215. doi:10.1159/000323444

85. del Valle MF, Pérez M, Santana-Sosa E, et al. Does resistance training improve the functional capacity and wellbeing of very young anorexic patients? A randomized controlled trial. J Adolesc Health. 2010;46(4):352-358. doi:10.1016/j.jadohealth.2009.09.001

86. Jenkins PE, Hoste RR, Doyle AC, et al. Health-related quality of life among adolescents with eating disorders. J Psychosom Res. 2014;76(1):1-5. doi:10.1016/j.jpsychores.2013.11.006

87. Endicott J, Nee J, Yang R, Wohlberg C. Pediatric Quality of Life Enjoyment and Satisfaction Questionnaire (PQ-LES-Q): Reliability and validity. J Am Acad Child Adolesc Psychiatry. 2006;45(4):401-407. doi:10.1097/01.chi.0000198590.38325.81

88. Kiss E, Kapornai K, Baji I, et al. Assessing quality of life: Mother-child agreement in depressed and non-depressed Hungarian. Eur Child Adolesc Psychiatry. 2009;18(5):265-273. doi:10.1007/s00787-008-0727-3

89. Connor DF, McLaughlin TJ, Jeffers-Terry M. Randomized controlled pilot study of quetiapine in the treatment of adolescent conduct disorder. J Child Adolesc Psychopharmacol. 2008;18(2):140-156. doi:10.1089/cap.2006.0007

90. Rotsika V, Coccossis M, Vlassopoulos M, et al. Does the subjective quality of life of children with specific learning disabilities (SpLD) agree with their parents' proxy reports? Qual Life Res. 2011;20(8):1271-1278. doi:10.1007/s11136-011-9857-z

91. Freeman AJ, Youngstrom EA, Michalak E, et al. Quality of life in pediatric bipolar disorder. Pediatrics. 2009;123(3):e446-e452. doi:10.1542/peds.2008-0841

92. Remschmidt H, Mattejat F. The quality of life of children and adolescents with ADHD undergoing outpatient psychiatric treatment: Simple disorders of activity and attention and hyperkinetic conduct disorders in comparison with each other and with other diagnostic groups. Atten Defic Hyperact Disord. 2010;2(4):161-170. doi:10.1007/s12402-010-0036-9

93. Wallander JL. Theoretical and developmental issues in quality of life for children and adolescents. In: Koot HM, Wallander JL (eds.), Quality of life in child and adolescent illness: Concepts, methods, and findings (pp. 23-48). New York, NY: Taylor and Francis, 2001.

**A thought-provoking synthesis of developmental considerations in pediatric QL assessment, its theoretical underpinnings and methodological applications.

94. Varni JW, Seid M, Rode CA. The PedsQL: Measurement model for the pediatric quality of life inventory. Med Care. 1999;37(2):126-139.

95. Ravens-Sieberer U, Gosch A, Abel T, et al. Quality of life in children and adolescents: A European public health perspective. Soz Praventivmed. 2001;46(5):294-302. doi: 10.1007/BF01321080

**An overall presentation of the theoretical foundations and methodological approaches for the European project "KIDSCREEN", which advanced a developmental perspective to the $Q L$ assessment of children and adolescents.

96. Bullinger M, Brütt AL, Erhart M, et al. Psychometric properties of the KINDL-R questionnaire: Results of the BELLA study. Eur Child Adolesc Psychiatry. 2008;17(S1):125-32. doi:10.1007/s00787-008-1014-z. 
97. Schmidt S, Debensason D, Mühlan H, et al. The DISABKIDS generic quality of life instrument showed cross-cultural validity. J Clin Epidemiol. 2006;59(6):587-598. doi: 10.1016/j.jclinepi.2005.09.012

98. Carona C, Moreira H, Silva N, et al. Social support and adaptation outcomes in children and adolescents with cerebral palsy. Disabil Rehabil. 2014;36(7):584-592. doi: 10.3109/09638288.2013.804596

99. Baars R, Atherton C, Koopman H, et al. The European DISABKIDS project: Development of seven condition-specific modules to measure health related quality of life in children and adolescents. Health Qual Life Outcomes. 2005;3:70. doi: 10.1186/1477-7525-3-70

100. Holmbeck GN. A developmental perspective on adolescent health and illness: An introduction to the special issues. J Pediatr Psychol. 2002;27(5):409-416. doi: 10.1093/jpepsy/27.5.409

101. Riley AW. Evidence that school-age children can self-report on their health. Ambul Pediatr. 2004;4(S4):371-376.

102. Varni JW, Limbers CA, Burwinkle TM. How young can children reliably and validly self-report their health-related quality of life?: An analysis of 8,591 children across age subgroups with the PedsQL 4.0 Generic Core Scales. Health Qual Life Outcomes. 2007;5:1. doi: 10.1186/14777525-5-1

103. Ravens-Sieberer U, Gosch A, Rajmil L, et al. KIDSCREEN-52 quality-of-life measure for children and adolescents. Expert Rev Pharmacoecon Outcomes Res. 2005;5(3):353-364. doi: $10.1586 / 14737167.5 .3 .353$

104. Theunissen NC, Vogels TG, Koopman HM, et al. The proxy problem: Child report versus parent report in health-related quality of life research. Qual Life Res. 1998;7(5):387-397. doi: 10.1023/A:1008801802877

105. Smith SR. Making sense of multiple informants in child and adolescent psychopathology - a guide for clinicians. J Psychoeduc Assess. 2007;25(2):139-149. doi: 10.1177/0734282906296233

106. Silva N, Crespo C, Carona C, et al. Why the (dis)agreement? Family context and child-parent perspectives on health-related quality of life and psychological problems in pediatric asthma. Child Care Health Dev. Forthcoming 2014. doi: 10.1111/cch.12147

107. Preacher KJ, Hayes AF. SPSS and SAS procedures for estimating indirect effects in simple mediation models. Behav Res Methods Instrum Comput. 2004;36(4):717-731. doi: 10.3758/BF03206553

108. Allmond BW Jr, Buckman W, Gofman HF. The family is the patient: An approach to behavioral pediatrics for the clinician. St Louis, MO: CV Mosby Co, 1979.

109. Moreira H, Carona C, Silva N, et al. Psychological and quality of life outcomes in pediatric populations: A parent-child perspective. J Pediatr. 2013;163(5):1471-1478. doi: 10.1016/j.jpeds.2013.06.028

110. Katschnig H. Quality of life in mental disorders: Challenges for research and clinical practice. World Psychiatry. 2006;5(3):139-145.

* A brief position paper describing the rationale, state-of-the-art and future directions of $Q L$ assessment in the context of psychological disorders.

111. Frisch MB. Improving mental and physical health care through quality of life therapy and assessment. In: Diener E, Rahtz DR (eds.), Advances in quality of life theory and research (pp. 207-241). Dordrecht: Kluwer, 2000

112. de Ridder, Geenen R, Kuijer R, van Middendorp H. Psychological adjustment to chronic disease. Lancet. 2008;372(9634):246-255. doi: 10.1016/S0140-6736(08)61078-8 
Table 1. Strategy used for searching the PsychINFO electronic database.

\begin{tabular}{|c|c|c|}
\hline Number & Search term & $\begin{array}{l}\text { Number of } \\
\text { records }\end{array}$ \\
\hline 1. & *"Quality of Life"/ & 21711 \\
\hline 2. & $\begin{array}{l}\text { (child or children or childhood or adolescent or adolescence or youth } \\
\text { or teen or pediatric or paediatric).ti. }\end{array}$ & 212242 \\
\hline 3. & $\begin{array}{l}\text { (child or children or childhood or adolescent or adolescence or youth } \\
\text { or teen or pediatric or paediatric).ab. }\end{array}$ & 427418 \\
\hline 4. & 2 or 3 & 451382 \\
\hline 5. & mental disorder.mp. or exp Mental Disorders/ & 386242 \\
\hline 6. & $\begin{array}{l}\text { (psychological problems or psychological disorder or psychiatric } \\
\text { disorder or mental disorder).ti. }\end{array}$ & 1683 \\
\hline 7. & $\begin{array}{l}\text { (psychological problems or psychological disorder or psychiatric } \\
\text { disorder or mental disorder).ab. }\end{array}$ & 14276 \\
\hline 8. & 5 or 6 or 7 & 390265 \\
\hline 9. & 1 and 4 and 8 & 334 \\
\hline 10. & limit 9 to (human and yr="1994 -Current") & 332 \\
\hline
\end{tabular}

Note: Searches were performed by using OvidSP, in which “.ti." represents title, ".ab." represents abstract, ".mp." represents multipurpose search, "exp" represents explode to include broader terms and related terms, and "yr" represents year of publication. 
Table 2. Study design and sample characteristics reported in the studies included in the systematic review.

\begin{tabular}{|c|c|c|c|c|c|c|c|c|c|}
\hline \multirow[b]{2}{*}{ Study } & \multicolumn{5}{|c|}{ Sample characteristics } & \multicolumn{3}{|c|}{ QoL assessment } & \multirow[b]{2}{*}{$\begin{array}{l}\text { Age group } \\
\text { analyses }\end{array}$} \\
\hline & Country & $\begin{array}{c}\text { Study design; } \\
\text { Period of } \\
\text { data } \\
\text { collection } \\
\end{array}$ & $\begin{array}{l}\text { Sample } \\
\text { size }\end{array}$ & $\begin{array}{c}\text { Age } \\
\text { (years) } \\
\text { Range; } \\
\text { M土SD }\end{array}$ & Diagnosis & $\begin{array}{c}\text { Informan } \\
\mathbf{t}\end{array}$ & Instrument & QoL dimensions & \\
\hline $\begin{array}{l}\text { Algorta et } \\
\text { al., } 2011\end{array}$ & USA & $\begin{array}{l}\text { Cross- } \\
\text { sectional }\end{array}$ & 138 & $\begin{array}{l}5-18 \\
11.18 \pm \\
3.55\end{array}$ & $\begin{array}{l}\text { Bipolar } \\
\text { spectrum } \\
\text { disorder }\end{array}$ & Proxy & KINDL-R & $\begin{array}{l}\text { Physical wellbeing, } \\
\text { Emotional wellbeing, } \\
\text { Self-esteem, Family, } \\
\text { Friends, School }\end{array}$ & $\begin{array}{l}\text { Correlation } \\
\text { coefficient } \\
\text { between } \\
\text { youth's age } \\
\text { and QL }\end{array}$ \\
\hline $\begin{array}{l}\text { Allen et al., } \\
2010\end{array}$ & Switzerland & $\begin{array}{l}\text { Cross- } \\
\text { sectional; }\end{array}$ & 94 & $\begin{array}{l}7-14 \\
10.18 \pm \\
1.72\end{array}$ & $\begin{array}{l}\text { Separation } \\
\text { anxiety } \\
\text { disorder } \\
(n=58) \text { and } \\
\text { other anxiety } \\
\text { disorders } \\
(n=36)\end{array}$ & $\begin{array}{l}\text { Self } \\
\text { Proxy }\end{array}$ & $\begin{array}{l}\text { Inventory for } \\
\text { the } \\
\text { assessment } \\
\text { of QL in } \\
\text { children and } \\
\text { adolescents }\end{array}$ & NR & NR \\
\hline $\begin{array}{l}\text { Bachmann et } \\
\text { al., } 2010\end{array}$ & Germany & $\begin{array}{l}\text { Cross- } \\
\text { sectional }\end{array}$ & 88 & $\begin{array}{l}6-18 \\
9.3 \pm 2.5\end{array}$ & Enuresis & $\begin{array}{l}\text { Self } \\
\text { Proxy }\end{array}$ & $\begin{array}{l}\text { PEMQOL-SF } \\
\text { DCGM-10 }\end{array}$ & $\begin{array}{l}\text { Child impact, Family } \\
\text { impact, Total score }\end{array}$ & $\begin{array}{l}\text { Pearson } \\
\text { correlation } \\
\text { coefficient } \\
\text { between age } \\
\text { and QL }\end{array}$ \\
\hline $\begin{array}{l}\text { Baghdadli et } \\
\text { al., } 2013\end{array}$ & France & Longitudinal; & 14 & $\begin{array}{l}8-12 \\
11.1 \pm 1.53\end{array}$ & $\begin{array}{l}\text { Autism } \\
\text { spectrum } \\
\text { disorder }\end{array}$ & Proxy & $\begin{array}{l}\text { KIDSCREEN } \\
-27\end{array}$ & $\begin{array}{l}\text { Physical wellbeing, } \\
\text { Psychological } \\
\text { wellbeing, } \\
\text { Autonomy and } \\
\text { parents, Social } \\
\text { support and peers, } \\
\text { School environment }\end{array}$ & NR \\
\hline $\begin{array}{l}\text { Bastiaansen } \\
\text { et al., } 2004\end{array}$ & $\begin{array}{l}\text { The } \\
\text { Netherlands }\end{array}$ & $\begin{array}{l}\text { Cross- } \\
\text { sectional; }\end{array}$ & 243 & $\begin{array}{l}6-18 \\
10.87 \pm 3.1\end{array}$ & $\begin{array}{l}\text { Six diagnostic } \\
\text { categories }\end{array}$ & $\begin{array}{l}\text { Self } \\
\text { Proxy }\end{array}$ & $\begin{array}{l}\text { PedsQL } 4.0 \\
\text { Generic Core } \\
\text { Scales }\end{array}$ & $\begin{array}{l}\text { Physical functioning, } \\
\text { Emotional } \\
\text { functioning, Social } \\
\text { functioning, School }\end{array}$ & $\begin{array}{l}\text { ANOVA by } \\
\text { age groups } \\
\text { (6-12 vs. } 13- \\
18 \text { years); }\end{array}$ \\
\hline
\end{tabular}




\begin{tabular}{|c|c|c|c|c|c|c|c|c|c|}
\hline & & & & & & & & $\begin{array}{l}\text { functioning, Total } \\
\text { summary score }\end{array}$ & $\begin{array}{l}\text { Agreement } \\
\text { between } \\
\text { informants } \\
\text { was examined } \\
\text { separately for } \\
\text { each age } \\
\text { group }\end{array}$ \\
\hline $\begin{array}{l}\text { Bastiaens, } \\
2008\end{array}$ & USA & Longitudinal & 84 & $\begin{array}{l}5-18 \\
11.1 \pm 3.3\end{array}$ & ADHD & Proxy & HALFS & Total score & $\begin{array}{l}\text { Correlations } \\
\text { coefficients } \\
\text { between age } \\
\text { and change in } \\
\text { QL scores }\end{array}$ \\
\hline $\begin{array}{l}\text { Bastiaens, } \\
2011\end{array}$ & USA & Longitudinal; & 75 & $\begin{array}{l}6-12 \\
9.0 \pm 2.1\end{array}$ & ADHD & Proxy & HALFS & Total score & NR \\
\hline $\begin{array}{l}\text { Becker et al., } \\
2011\end{array}$ & Multicentric & Longitudinal & 721 & $6-17$ & ADHD & $\begin{array}{l}\text { Self } \\
\text { Proxy }\end{array}$ & KINDL & $\begin{array}{l}\text { Physical wellbeing, } \\
\text { Emotional wellbeing, } \\
\text { Self-esteem, Family, } \\
\text { Friends, School }\end{array}$ & $\begin{array}{l}\text { Separate } \\
\text { analyses for } \\
\text { children aged } \\
6-11 \text { and } \\
\text { adolescents } \\
\text { aged 12-17 } \\
\text { years } \\
\end{array}$ \\
\hline $\begin{array}{l}\text { Bernard et } \\
\text { al., } 2009\end{array}$ & USA & $\begin{array}{l}\text { Cross- } \\
\text { sectional }\end{array}$ & 56 & $\begin{array}{l}5-17 \\
10.46 \pm 2.9\end{array}$ & $\begin{array}{l}\text { Gilles de la } \\
\text { Tourette } \\
\text { syndrome }\end{array}$ & Proxy & TACQOL & $\begin{array}{l}\text { Physical complains, } \\
\text { Motor functioning, } \\
\text { Autonomy, Cognitive } \\
\text { functioning, Social } \\
\text { functioning, Positive } \\
\text { emotions, Negative } \\
\text { emotions }\end{array}$ & $\begin{array}{l}\text { Regression } \\
\text { analyses with } \\
\text { age as a } \\
\text { predictor of } \\
\text { QL scores }\end{array}$ \\
\hline $\begin{array}{l}\text { Connor et } \\
\text { al., } 2008\end{array}$ & USA & Longitudinal; & 19 & $\begin{array}{l}12-17 \\
14.1 \pm 1.6\end{array}$ & $\begin{array}{l}\text { Conduct } \\
\text { disorder }\end{array}$ & Proxy & PQ-LES-Q & Total score & NR \\
\hline Cutler et al., & UK & Cross- & 57 & $8-17$ & Gilles de la & Self & PedsQL 4.0 & Physical functioning, & NR \\
\hline
\end{tabular}




\begin{tabular}{|c|c|c|c|c|c|c|c|c|c|}
\hline 2009 & & sectional; & & $11.4 \pm 2.36$ & $\begin{array}{l}\text { Tourette } \\
\text { syndrome }\end{array}$ & & $\begin{array}{l}\text { Generic Core } \\
\text { Scales }\end{array}$ & $\begin{array}{l}\text { Emotional } \\
\text { functioning, Social } \\
\text { functioning, School } \\
\text { functioning, Total } \\
\text { summary score }\end{array}$ & \\
\hline $\begin{array}{l}\text { Cuypers et } \\
\text { al., } 2011\end{array}$ & Norway & Longitudinal & 5 & $10-11$ & ADHD & $\begin{array}{l}\text { Self } \\
\text { Proxy }\end{array}$ & KINDL-R & $\begin{array}{l}\text { Physical wellbeing, } \\
\text { Emotional wellbeing, } \\
\text { Self-esteem, Family, } \\
\text { Friends, School }\end{array}$ & NR \\
\hline $\begin{array}{l}\text { de Souza et } \\
\text { al., } 2013\end{array}$ & Brazil & Longitudinal; & 28 & $\begin{array}{l}10-13 \\
12 \pm 0.77\end{array}$ & $\begin{array}{l}\text { Anxiety } \\
\text { disorders }\end{array}$ & Self & YQOL-R & NR & $\begin{array}{l}\text { Age as } \\
\text { covariate in } \\
\text { comparison } \\
\text { analyses }\end{array}$ \\
\hline $\begin{array}{l}\text { del Valle et } \\
\text { al., } 2010\end{array}$ & Spain & Longitudinal & 22 & $\begin{array}{l}12-16 \\
14.45 \pm \\
0.96\end{array}$ & $\begin{array}{l}\text { Restrictive } \\
\text { Anorexia } \\
\text { Nervosa }\end{array}$ & Self & SF-36 & $\begin{array}{l}\text { Physical functioning, } \\
\text { Physical role, Pain, } \\
\text { General health, } \\
\text { Vitality, Social } \\
\text { functioning, } \\
\text { Emotional role, } \\
\text { Mental health, } \\
\text { Physical component } \\
\text { scale, Mental } \\
\text { component scale }\end{array}$ & NR \\
\hline $\begin{array}{l}\text { Delahaye et } \\
\text { al., } 2014\end{array}$ & USA & $\begin{array}{l}\text { Cross- } \\
\text { sectional }\end{array}$ & 86 & $\begin{array}{l}4-12 \\
7.18 \pm \mathrm{NR}\end{array}$ & $\begin{array}{l}\text { Autism } \\
\text { Spectrum } \\
\text { Disorders }\end{array}$ & Proxy & $\begin{array}{l}\text { PedsQL } 4.0 \\
\text { Generic Core } \\
\text { Scales }\end{array}$ & $\begin{array}{l}\text { Physical summary } \\
\text { score, Psychosocial } \\
\text { summary score, Total } \\
\text { score }\end{array}$ & $\begin{array}{l}\text { Age as } \\
\text { covariate in } \\
\text { regression } \\
\text { analyses } \\
\end{array}$ \\
\hline $\begin{array}{l}\text { Dey et al., } \\
2012\end{array}$ & Switzerland & $\begin{array}{l}\text { Cross- } \\
\text { sectional }\end{array}$ & 535 & $\begin{array}{l}9-14 \\
11.39 \pm \\
1.45\end{array}$ & $\begin{array}{l}\text { Multiple } \\
\text { diagnostic } \\
\text { categories }\end{array}$ & $\begin{array}{l}\text { Self } \\
\text { Proxy }\end{array}$ & $\begin{array}{l}\text { KIDSCREEN } \\
-27\end{array}$ & $\begin{array}{l}\text { Physical wellbeing, } \\
\text { Psychological } \\
\text { wellbeing, } \\
\text { Autonomy and parent } \\
\text { relations, } \\
\text { Social support and } \\
\text { peers, School } \\
\text { environment }\end{array}$ & NR \\
\hline
\end{tabular}




\begin{tabular}{|c|c|c|c|c|c|c|c|c|}
\hline $\begin{array}{l}\text { Eddy et al., } \\
2011\end{array}$ & Italy & Cross-sectional 50 & $\begin{array}{l}11-17 \\
13.26 \pm 2.32\end{array}$ & $\begin{array}{l}\text { Gilles de la } \\
\text { Tourette } \\
\text { syndrome }+ \\
\text { comorbid } \\
\text { obsessive- } \\
\text { compulsive } \\
\text { disorder or } \\
\text { ADHD }\end{array}$ & Self & YQOL-R & $\begin{array}{l}\text { Self domain, } \\
\text { Relationship domain, } \\
\text { Environment domain, } \\
\text { General domain, } \\
\text { Total score }\end{array}$ & $\begin{array}{l}\text { Age as } \\
\text { covariate in } \\
\text { comparison } \\
\text { analyses } \\
\text { (ANCOVA) }\end{array}$ \\
\hline $\begin{array}{l}\text { Endicott et } \\
\text { al., } 2006\end{array}$ & USA & Longitudinal & $\begin{array}{l}6-17 \\
11.95 \pm 3.10\end{array}$ & $\begin{array}{l}\text { Major } \\
\text { depressive } \\
\text { disorder }\end{array}$ & Self & PQ-LES-Q & Total score & $\begin{array}{l}\text { QL scores } \\
\text { were } \\
\text { compared } \\
\text { between age } \\
\text { groups (6-11, } \\
\text { 12-17); } \\
\text { Cronbach's } \\
\text { alphas and } \\
\text { Pearson } \\
\text { correlations } \\
\text { between } \\
\text { measures } \\
\text { were } \\
\text { computed } \\
\text { separately for } \\
\text { each age } \\
\text { group }\end{array}$ \\
\hline $\begin{array}{l}\text { Ertan et al., } \\
2009\end{array}$ & Turkey & $\begin{array}{ll}\text { Cross- } & 44 \\
\text { sectional; } & \end{array}$ & $\begin{array}{l}6-15 \\
9.9 \pm 2.9\end{array}$ & Enuresis & Self & KINDL & $\begin{array}{l}\text { Physical wellbeing, } \\
\text { Emotional wellbeing, } \\
\text { Self-esteem, Family, } \\
\text { Friends, School, } \\
\text { Total score }\end{array}$ & $\begin{array}{l}\text { Correlation } \\
\text { coefficient } \\
\text { between } \\
\text { youth's age } \\
\text { and QL (but } \\
\text { comparison } \\
\text { analysis } \\
\text { between } \\
\text { enuresis and } \\
\text { control }\end{array}$ \\
\hline
\end{tabular}




\begin{tabular}{|c|c|c|c|c|c|c|c|c|c|}
\hline & & & & & & & & & $\begin{array}{l}\text { groups did } \\
\text { not include } \\
\text { age) }\end{array}$ \\
\hline $\begin{array}{l}\text { Escobar et } \\
\text { al., } 2005\end{array}$ & Spain & $\begin{array}{l}\text { Cross- } \\
\text { sectional; }\end{array}$ & 120 & $\begin{array}{l}6-12 \\
9.3 \pm 2.0\end{array}$ & ADHD & Proxy & CHQ & $\begin{array}{l}\text { Physical functioning, } \\
\text { Role/ social } \\
\text { limitations - } \\
\text { emotional/behavioral, } \\
\text { Role/social limitations } \\
\text {-physical, Bodily } \\
\text { pain/discomfort, } \\
\text { Behavior, Mental } \\
\text { health, Self-esteem, } \\
\text { General health } \\
\text { perceptions, Parent } \\
\text { impact - emotional, } \\
\text { Parent impact - time, } \\
\text { Family activities, } \\
\text { Family cohesion, } \\
\text { Physical summary } \\
\text { score, Psychosocial } \\
\text { summary score }\end{array}$ & NR \\
\hline $\begin{array}{l}\text { Findling et } \\
\text { al., } 2013\end{array}$ & USA & Longitudinal & 265 & $\begin{array}{l}13-17 \\
14.5 \pm 1.3\end{array}$ & ADHD & Self & YQOL-R & $\begin{array}{l}\text { Self, Relationship, } \\
\text { Environment, } \\
\text { General QOL, Total } \\
\text { score }\end{array}$ & NR \\
\hline $\begin{array}{l}\text { Flapper et } \\
\text { al., } 2008\end{array}$ & $\begin{array}{l}\text { The } \\
\text { Netherlands }\end{array}$ & Longitudinal & 23 & $\begin{array}{l}7-10 \\
8.5 \pm 0.25\end{array}$ & $\begin{array}{l}\text { ADHD and } \\
\text { Developmental } \\
\text { coordination } \\
\text { disorder }\end{array}$ & $\begin{array}{l}\text { Self } \\
\text { Proxy }\end{array}$ & $\begin{array}{l}\text { DUX-25 } \\
\text { TACQOL }\end{array}$ & $\begin{array}{l}\text { Physical, Home, } \\
\text { Emotional, Social, } \\
\text { Total Score } \\
\text { Bodily functioning, } \\
\text { Motor functioning, } \\
\text { Autonomic } \\
\text { functioning, Cognitive } \\
\text { functioning, Social } \\
\text { functioning, Positive } \\
\text { moods, Negative }\end{array}$ & NR \\
\hline
\end{tabular}




\begin{tabular}{|c|c|c|c|c|c|c|c|c|c|}
\hline & & & & & & & & moods, Total score & \\
\hline $\begin{array}{l}\text { Freeman et } \\
\text { al., } 2009\end{array}$ & USA & Cross-sectional & 529 & $\begin{array}{l}8-18 \\
12.0 \pm 2.6\end{array}$ & $\begin{array}{l}\text { Bipolar } \\
\text { disorder, } \\
\text { unipolar } \\
\text { disorder, } \\
\text { behavioral } \\
\text { disorder and } \\
\text { other } \\
\text { diagnosis }\end{array}$ & Proxy & KINDL-R & $\begin{array}{l}\text { Physical wellbeing, } \\
\text { Emotional wellbeing, } \\
\text { Self-esteem, Family, } \\
\text { Friends, School, } \\
\text { Total score }\end{array}$ & $\begin{array}{l}\text { Correlation } \\
\text { coefficient } \\
\text { between } \\
\text { youth's age } \\
\text { and QL; Age } \\
\text { as covariate } \\
\text { in regression } \\
\text { analyses (but } \\
\text { comparison } \\
\text { analysis } \\
\text { between } \\
\text { diagnostic } \\
\text { groups did } \\
\text { not include } \\
\text { age) }\end{array}$ \\
\hline $\begin{array}{l}\text { Goulardins et } \\
\text { al., } 2011\end{array}$ & Brazil & $\begin{array}{l}\text { Cross- } \\
\text { sectional; }\end{array}$ & 14 & $\begin{array}{l}7-10 \\
9.28 \pm 1.13\end{array}$ & ADHD & Self & $\begin{array}{l}\text { PedsQL } 4.0 \\
\text { Generic Core } \\
\text { Scales }\end{array}$ & $\begin{array}{l}\text { Emotional } \\
\text { functioning, Social } \\
\text { functioning, School } \\
\text { functioning, Physical } \\
\text { health summary } \\
\text { score, Psychosocial } \\
\text { health summary } \\
\text { score, Total score }\end{array}$ & NR \\
\hline $\begin{array}{l}\text { Görtz-Dorten } \\
\text { et al., } 2011\end{array}$ & $\begin{array}{l}\text { Germany } \\
11 / 2006- \\
12 / 2007\end{array}$ & Longitudinal & $\begin{array}{l}589 \text { parents } \\
552 \\
\text { patients }\end{array}$ & $6-17$ & ADHD & $\begin{array}{l}\text { Self } \\
\text { Proxy }\end{array}$ & $\begin{array}{l}\text { KINDL } \\
\text { (KID and } \\
\text { KIDDO) }\end{array}$ & $\begin{array}{l}\text { Physical wellbeing, } \\
\text { Emotional wellbeing, } \\
\text { Self-esteem, Family, } \\
\text { Friends, School, } \\
\text { Total score }\end{array}$ & $\begin{array}{l}\text { Correlations } \\
\text { between QL } \\
\text { and other } \\
\text { measures } \\
\text { were } \\
\text { computed } \\
\text { separately for } \\
\text { parents, } \\
\text { children, and } \\
\text { adolescents }\end{array}$ \\
\hline
\end{tabular}




\begin{tabular}{|c|c|c|c|c|c|c|c|c|c|}
\hline $\begin{array}{l}\text { Gürkan et } \\
\text { al., } 2010\end{array}$ & Turkey & Longitudinal & 45 & $\begin{array}{l}8-14 \\
10.09 \pm 1.80\end{array}$ & ADHD & $\begin{array}{l}\text { Self } \\
\text { Proxy }\end{array}$ & $\begin{array}{l}\text { PedsQL } \\
\text { Generic Core } \\
\text { Scales }\end{array}$ & $\begin{array}{l}\text { Physical summary } \\
\text { score, Psychosocial } \\
\text { summary score, Total } \\
\text { score }\end{array}$ & NR \\
\hline $\begin{array}{l}\text { Jafari et al., } \\
2010\end{array}$ & Iran & Cross-sectional & 72 & $\begin{array}{l}8-18 \\
11.4 \pm 2.01\end{array}$ & ADHD & $\begin{array}{l}\text { Self } \\
\text { Proxy }\end{array}$ & $\begin{array}{l}\text { PedsQL } 4.0 \\
\text { Generic Core } \\
\text { Scales }\end{array}$ & $\begin{array}{l}\text { Emotional } \\
\text { functioning, Social } \\
\text { functioning, School } \\
\text { functioning, Physical } \\
\text { health summary } \\
\text { score, Psychosocial } \\
\text { health summary } \\
\text { score, Total score }\end{array}$ & NR \\
\hline $\begin{array}{l}\text { Jenkins et } \\
\text { al., } 2014\end{array}$ & USA & $\begin{array}{l}\text { Cross- } \\
\text { sectional; }\end{array}$ & 67 & $\begin{array}{l}11-18 \\
16.5 \pm 2.0\end{array}$ & $\begin{array}{l}\text { Eating } \\
\text { disorders } \\
\text { (anorexia } \\
\text { nervosa, } \\
\text { bulimia } \\
\text { nervosa, or } \\
\text { eating disorder } \\
\text { not otherwise } \\
\text { specified) }\end{array}$ & Self & SF-36 & $\begin{array}{l}\text { Physical Health } \\
\text { Composite Score, } \\
\text { Mental Health } \\
\text { Composite Score }\end{array}$ & NR \\
\hline $\begin{array}{l}\text { Kern et al., } \\
2011\end{array}$ & USA & Longitudinal & 24 & $\begin{array}{l}3-12 \\
7.8 \pm 2.9\end{array}$ & $\begin{array}{l}\text { Autism } \\
\text { spectrum } \\
\text { disorder }\end{array}$ & Proxy & PQ-LES-Q & $\begin{array}{l}\text { General activities } \\
\text { sub-scale }\end{array}$ & NR \\
\hline $\begin{array}{l}\text { Kiss et al., } \\
2009\end{array}$ & Hungary & Cross-sectional & 248 & $\begin{array}{l}7-14 \\
11.45 \pm 2.02\end{array}$ & $\begin{array}{l}\text { Major } \\
\text { depressive } \\
\text { disorder }\end{array}$ & $\begin{array}{l}\text { Self } \\
\text { Proxy }\end{array}$ & ILK & $\begin{array}{l}\text { School, Family, Peer } \\
\text { relations, Alone } \\
\text { activities, Physical } \\
\text { health, Mental health, } \\
\text { Global QL }\end{array}$ & $\begin{array}{l}\text { Regression } \\
\text { analyses with } \\
\text { age as a } \\
\text { predictor of } \\
\text { mother-child } \\
\text { agreement } \\
\text { about child's } \\
\text { QL }\end{array}$ \\
\hline $\begin{array}{l}\text { Klassen et } \\
\text { al., } 2004\end{array}$ & Canada & $\begin{array}{l}\text { Cross- } \\
\text { sectional; }\end{array}$ & 131 & $\begin{array}{l}6-17 \\
10.0 \pm 2.8\end{array}$ & $\begin{array}{l}\text { ADHD + } \\
\text { comorbid }\end{array}$ & Proxy & CHQ & $\begin{array}{l}\text { Physical functioning, } \\
\text { Role/ social }\end{array}$ & $\begin{array}{l}\text { Correlation } \\
\text { coefficient }\end{array}$ \\
\hline
\end{tabular}




\begin{tabular}{|c|c|c|c|c|c|c|c|c|}
\hline & & & & $\begin{array}{l}\text { diagnosis } \\
\text { (learning } \\
\text { disabilities, } \\
\text { oppositional } \\
\text { defiant disorder } \\
\text { or conduct } \\
\text { disorder or } \\
\text { other) }\end{array}$ & & & $\begin{array}{l}\text { limitations - } \\
\text { emotional/behavioral, } \\
\text { Role/social limitations } \\
\text {-physical, Bodily } \\
\text { pain/discomfort, } \\
\text { Behavior, Mental } \\
\text { health, Self-esteem, } \\
\text { General health } \\
\text { perceptions, Parent } \\
\text { impact - emotional, } \\
\text { Parent impact - time, } \\
\text { Family activities, } \\
\text { Family cohesion, } \\
\text { Physical summary } \\
\text { score, Psychosocial } \\
\text { summary score }\end{array}$ & $\begin{array}{l}\text { between } \\
\text { youth's age } \\
\text { and QL; } \\
\text { Regression } \\
\text { analyses with } \\
\text { age as a } \\
\text { predictor of } \\
\text { QL scores }\end{array}$ \\
\hline $\begin{array}{l}\text { Kose et al., } \\
2013\end{array}$ & Turkey & Cross-sectional 102 & $\begin{array}{l}3-18 \\
8.2 \pm 3.7\end{array}$ & $\begin{array}{l}\text { Autism } \\
\text { spectrum } \\
\text { disorder }\end{array}$ & Proxy & $\begin{array}{l}\text { PedsQL } 4.0 \\
\text { Generic Core } \\
\text { Scales }\end{array}$ & $\begin{array}{l}\text { Emotional } \\
\text { functioning, Social } \\
\text { functioning, School } \\
\text { functioning, Physical } \\
\text { health summary } \\
\text { score, Psychosocial } \\
\text { health summary } \\
\text { score, Total score }\end{array}$ & $\begin{array}{l}\text { QL scores } \\
\text { were } \\
\text { compared } \\
\text { (ANOVA) } \\
\text { between age } \\
\text { groups (not } \\
\text { specified) }\end{array}$ \\
\hline $\begin{array}{l}\text { Kuhlthau et } \\
\text { al., } 2010\end{array}$ & $\begin{array}{l}\text { USA } \\
\text { Canada }\end{array}$ & $\begin{array}{l}\text { Cross- } \\
\text { sectional; }\end{array}$ & $2-17$ & $\begin{array}{l}\text { Autism } \\
\text { spectrum } \\
\text { disorder }\end{array}$ & Proxy & $\begin{array}{l}\text { PedsQL } 4.0 \\
\text { Generic Core } \\
\text { Scales }\end{array}$ & $\begin{array}{l}\text { Emotional } \\
\text { functioning, Social } \\
\text { functioning, School } \\
\text { functioning, Physical } \\
\text { health summary } \\
\text { score, Psychosocial } \\
\text { health summary } \\
\text { score, Total score }\end{array}$ & $\begin{array}{l}\text { QL scores } \\
\text { were } \\
\text { compared } \\
\text { between age } \\
\text { groups }(2-4, \\
5-7,8-12 \text {, } \\
\geq 13)\end{array}$ \\
\hline $\begin{array}{l}\text { Lack et al., } \\
2009\end{array}$ & USA & $\begin{array}{l}\text { Cross- } \\
\text { sectional; }\end{array}$ & $\begin{array}{l}8-17 \\
12.56 \pm 3.57\end{array}$ & $\begin{array}{l}\text { Obsessive- } \\
\text { compulsive } \\
\text { disorder }+\end{array}$ & $\begin{array}{l}\text { Self } \\
\text { Proxy }\end{array}$ & $\begin{array}{l}\text { PedsQL } 4.0 \\
\text { Generic Core } \\
\text { Scales }\end{array}$ & $\begin{array}{l}\text { Emotional } \\
\text { functioning, Social } \\
\text { functioning, School }\end{array}$ & $\begin{array}{l}\text { QL scores } \\
\text { were } \\
\text { compared }\end{array}$ \\
\hline
\end{tabular}




\begin{tabular}{|c|c|c|c|c|c|c|c|c|}
\hline & & & & $\begin{array}{l}\text { comorbid } \\
\text { diagnosis } \\
\text { (disruptive } \\
\text { behavior } \\
\text { disorders, } \\
\text { generalized } \\
\text { anxiety } \\
\text { disorder, } \\
\text { others) }\end{array}$ & & & $\begin{array}{l}\text { functioning, Physical } \\
\text { health summary } \\
\text { score, Psychosocial } \\
\text { health summary } \\
\text { score, Total score }\end{array}$ & $\begin{array}{l}\text { (ANOVA) } \\
\text { between age } \\
\text { groups (6-11, } \\
12-17) \text {. } \\
\text { Pearson } \\
\text { correlations } \\
\text { computed } \\
\text { separately for } \\
\text { each age } \\
\text { group }\end{array}$ \\
\hline $\begin{array}{l}\text { Limbers et } \\
\text { al., } 2011\end{array}$ & USA & Cross-sectional 22 & $\begin{array}{l}6-12 \\
9.25 \pm 2.15\end{array}$ & $\begin{array}{l}\text { Autism } \\
\text { spectrum } \\
\text { disorder }\end{array}$ & Proxy & $\begin{array}{l}\text { PedsQL } 4.0 \\
\text { Generic Core } \\
\text { Scales + } \\
\text { Cognitive } \\
\text { Functioning } \\
\text { Scale }\end{array}$ & $\begin{array}{l}\text { Emotional } \\
\text { functioning, Social } \\
\text { functioning, } \\
\text { Psychosocial Health } \\
\text { Summary Score, } \\
\text { School-Related } \\
\text { Cognitive } \\
\text { Functioning, Missed } \\
\text { School, School } \\
\text { Functioning } \\
\text { Summary Score, } \\
\text { Physical Health } \\
\text { Summary Score, } \\
\text { Cognitive } \\
\text { Functioning }\end{array}$ & NR \\
\hline $\begin{array}{l}\text { Naitoh et al., } \\
2012\end{array}$ & Japan & Longitudinal; 139 & $\begin{array}{l}\text { Range NR } \\
9.7 \pm 2.6\end{array}$ & Enuresis & $\begin{array}{l}\text { Self } \\
\text { Proxy }\end{array}$ & KINDL & $\begin{array}{l}\text { Physical wellbeing, } \\
\text { Emotional wellbeing, } \\
\text { Self-esteem, Family, } \\
\text { Friends, School }\end{array}$ & NR \\
\hline $\begin{array}{l}\text { Newcorn et } \\
\text { al., } 2005\end{array}$ & USA & Longitudinal 293 & $\begin{array}{l}8-18 \\
11.14 \pm \\
2.28\end{array}$ & $\begin{array}{l}\text { ADHD (with } \\
\text { oppositional } \\
\text { defiant } \\
\text { disorder, } n= \\
115 \text { ) }\end{array}$ & Proxy & $\begin{array}{l}\text { CHQ - } \\
\text { Parent form }\end{array}$ & $\begin{array}{l}\text { Role-emotional, } \\
\text { Behavior, Mental } \\
\text { health, Self-esteem, } \\
\text { Parent impact- } \\
\text { emotional, Parent } \\
\text { impact-time, Family }\end{array}$ & NR \\
\hline
\end{tabular}




\begin{tabular}{|c|c|c|c|c|c|c|c|c|}
\hline & & & & & & & $\begin{array}{l}\text { activities, } \\
\text { Psychosocial } \\
\text { Summary Score }\end{array}$ & \\
\hline $\begin{array}{l}\text { Niederkirchn } \\
\text { er et al., } \\
2011\end{array}$ & Germany & Longitudinal 42 & $\begin{array}{l}6-18 \\
11.8 \pm 3.0\end{array}$ & ADHD & $\begin{array}{l}\text { Self } \\
\text { Proxy }\end{array}$ & ILK & $\begin{array}{l}\text { School performance, } \\
\text { Family functioning, } \\
\text { Social integration, } \\
\text { Interests and } \\
\text { hobbies, Physical } \\
\text { health, Mental health, } \\
\text { Overall HRQL, } \\
\text { Burden of } \\
\text { disease, Burden of } \\
\text { treatments }\end{array}$ & NR \\
\hline $\begin{array}{l}\text { Olsen et al., } \\
2012\end{array}$ & $\begin{array}{l}\text { USA and } \\
\text { Puerto Rico }\end{array}$ & Longitudinal; 161 & $\begin{array}{l}13-17 \\
15.2 \pm 1.3\end{array}$ & $\begin{array}{l}\text { Manic or } \\
\text { mixed episode } \\
\text { associated } \\
\text { with bipolar I } \\
\text { disorder }\end{array}$ & Proxy & $\begin{array}{l}\mathrm{CHQ}- \\
\text { Parent form }\end{array}$ & $\begin{array}{l}\text { Bodily pain, General } \\
\text { health, Physical } \\
\text { functioning, } \\
\text { Role/social- physical, } \\
\text { Family activities, } \\
\text { Parent impact- } \\
\text { emotional, Mental } \\
\text { health, Self-esteem, } \\
\text { Behavior, Role/social- } \\
\text { emotional/behavioral, } \\
\text { Parent impact-time, } \\
\text { Family cohesion, } \\
\text { Physical Summary, } \\
\text { Psychosocial } \\
\text { Summary }\end{array}$ & NR \\
\hline $\begin{array}{l}\text { Patrick et al., } \\
2002\end{array}$ & USA & Longitudinal 68 & $12-18$ & ADHD & Self & $\begin{array}{l}\text { YQOL-R - } \\
\text { Perceptual } \\
\text { module } \\
\text { KINDL }\end{array}$ & $\begin{array}{l}\text { Self, Relationship, } \\
\text { Environment, } \\
\text { General QL, Total } \\
\text { perceptual score } \\
\text { Physical wellbeing, } \\
\text { Emotional wellbeing, } \\
\text { Self-esteem, Family, }\end{array}$ & $\begin{array}{l}\text { Age was } \\
\text { included as } \\
\text { covariate }\end{array}$ \\
\hline
\end{tabular}




\begin{tabular}{|c|c|c|c|c|c|c|c|c|c|}
\hline & & & & & & & & Friends, School & \\
\hline $\begin{array}{l}\text { Perwien et } \\
\text { al., } 2006\end{array}$ & USA & Longitudinal & 728 & $\begin{array}{l}6-17 \\
11.1 \pm 2.8\end{array}$ & ADHD & Proxy & $\begin{array}{l}\text { CHQ - } \\
\text { Parent form }\end{array}$ & $\begin{array}{l}\text { Bodily pain, General } \\
\text { health, Physical } \\
\text { functioning, } \\
\text { Role/social- physical, } \\
\text { Family activities, } \\
\text { Parent impact- } \\
\text { emotional, Mental } \\
\text { health, Self-esteem, } \\
\text { Behavior, Role/social- } \\
\text { emotional/behavioral, } \\
\text { Parent impact-time, } \\
\text { Family cohesion, } \\
\text { Physical Summary, } \\
\text { Psychosocial } \\
\text { Summary }\end{array}$ & $\begin{array}{l}\text { Age as a } \\
\text { predictor of } \\
\text { long-term } \\
\text { changes in } \\
\text { QL scores } \\
\text { (ANOVA } \\
\text { models) }\end{array}$ \\
\hline $\begin{array}{l}\text { Rademacher } \\
\text { et al., } 2007\end{array}$ & USA & Longitudinal & 23 & $15.0 \pm 1.1$ & $\begin{array}{l}\text { Manic or } \\
\text { mixed episode } \\
\text { associated } \\
\text { with bipolar I } \\
\text { disorder }\end{array}$ & Proxy & $\begin{array}{l}\text { CHQ - } \\
\text { Parent form }\end{array}$ & $\begin{array}{l}\text { Behavior, Bodily } \\
\text { Pain, Change in } \\
\text { Health, Family } \\
\text { Activities, Family } \\
\text { Cohesion, Global } \\
\text { Behavior, General } \\
\text { Health, Mental } \\
\text { Health, Parental } \\
\text { Impact-Emotional, } \\
\text { Physical Functioning, } \\
\text { Parental Impact- } \\
\text { Time, Role/Social- } \\
\text { Emotional/Behaviora } \\
\text { 1, Role/social- } \\
\text { Physical, } \\
\text { Self-Esteem }\end{array}$ & NR \\
\hline $\begin{array}{l}\text { Remschmidt } \\
\text { et al., } 2010\end{array}$ & Germany & Longitudinal & 726 & $8.7 \pm 3.0$ & $\begin{array}{l}\text { Multiple } \\
\text { diagnostic } \\
\text { categories }\end{array}$ & Proxy & ILK & $\begin{array}{l}\text { School performance, } \\
\text { Family functioning, } \\
\text { Social integration, }\end{array}$ & NR \\
\hline
\end{tabular}




\begin{tabular}{|c|c|c|c|c|c|c|c|c|c|}
\hline & & & & & & & & $\begin{array}{l}\text { Interests and } \\
\text { hobbies, Physical } \\
\text { health, Mental health, } \\
\text { Overall HRQL, } \\
\text { Burden of } \\
\text { disease, Burden of } \\
\text { treatments }\end{array}$ & \\
\hline $\begin{array}{l}\text { Rentz et al., } \\
2005\end{array}$ & USA & Longitudinal & 921 & $\begin{array}{l}6-18 \\
11.0 \pm \mathrm{NR}\end{array}$ & $\mathrm{ADHD}$ & Proxy & $\begin{array}{l}\text { CHQ - } \\
\text { Parent form }\end{array}$ & $\begin{array}{l}\text { Physical functioning, } \\
\text { Role limitations- } \\
\text { emotional/behavioral, } \\
\text { Role limitations- } \\
\text { physical, Bodily pain, } \\
\text { Behavior, Mental } \\
\text { health, Self-esteem, } \\
\text { General health } \\
\text { perceptions, Parental } \\
\text { impact-emotional, } \\
\text { Parental impact-time, } \\
\text { Family activities, } \\
\text { Family cohesion, } \\
\text { Physical summary } \\
\text { score, Psychosocial } \\
\text { summary score }\end{array}$ & $\begin{array}{l}\text { Age as } \\
\text { covariate in } \\
\text { ANCOVAs }\end{array}$ \\
\hline $\begin{array}{l}\text { Rizzo et al., } \\
2012\end{array}$ & Italy & Longitudinal & 100 & $\begin{array}{l}13-18 \\
16.03 \pm \\
1.32\end{array}$ & $\begin{array}{l}\text { Gilles de la } \\
\text { Tourette } \\
\text { syndrome }\end{array}$ & Self & YQOL-R & $\begin{array}{l}\text { Self, Relationship, } \\
\text { Environment, } \\
\text { General QL, Total } \\
\text { score }\end{array}$ & NR \\
\hline $\begin{array}{l}\text { Rothenberger } \\
\text { et al., } 2011\end{array}$ & Germany & Longitudinal & 822 & $\begin{array}{l}6-17 \\
10.1 \pm 2.5\end{array}$ & ADHD & $\begin{array}{l}\text { Self } \\
\text { Proxy }\end{array}$ & KINDL & $\begin{array}{l}\text { Physical wellbeing, } \\
\text { Emotional wellbeing, } \\
\text { Self-esteem, Family, } \\
\text { Friends, School }\end{array}$ & $\begin{array}{l}\text { Separate } \\
\text { analyses for } \\
\text { children aged } \\
6-11 \text { and for } \\
\text { adolescents } \\
\text { aged 12-17 } \\
\text { years }\end{array}$ \\
\hline Rotsika et & Greece & Cross- & 116 & $8-14$ & Specific & Self & KINDL & Physical wellbeing, & NR \\
\hline
\end{tabular}




\begin{tabular}{|c|c|c|c|c|c|c|c|c|c|}
\hline al., 2011 & & sectional & & $\begin{array}{l}10.67 \pm \\
1.99\end{array}$ & $\begin{array}{l}\text { learning } \\
\text { disabilities } \\
\text { (specific } \\
\text { reading } \\
\text { disorder, } \\
\text { spelling } \\
\text { disorder) }\end{array}$ & Proxy & & $\begin{array}{l}\text { Emotional wellbeing, } \\
\text { Self-esteem, Family, } \\
\text { Friends, School }\end{array}$ & \\
\hline $\begin{array}{l}\text { Sawyer et } \\
\text { al., } 2002\end{array}$ & Australia & $\begin{array}{l}\text { Cross- } \\
\text { sectional }\end{array}$ & 396 & $\begin{array}{l}6-17 \\
10.62 \pm \\
3.33\end{array}$ & $\begin{array}{l}\text { ADHD, major } \\
\text { depressive } \\
\text { disorder, or } \\
\text { conduct } \\
\text { disorder }\end{array}$ & Proxy & $\begin{array}{l}\mathrm{CHQ}- \\
\text { Parent form }\end{array}$ & $\begin{array}{l}\text { General health } \\
\text { perceptions, Pain and } \\
\text { discomfort, Self- } \\
\text { esteem, Emotional } \\
\text { problems, Behavioral } \\
\text { problems, Family } \\
\text { activities, Peer and } \\
\text { school activities due } \\
\text { to emotional/ } \\
\text { behavioral problems, } \\
\text { Emotional impact on } \\
\text { parents, Time impact } \\
\text { on parents, Physical } \\
\text { activities, Peer and } \\
\text { school activities due } \\
\text { to physical health } \\
\text { problems }\end{array}$ & $\begin{array}{l}\text { Age as } \\
\text { covariate in } \\
\text { ANCOVAs } \\
\text { and } \\
\text { regression } \\
\text { analyses }\end{array}$ \\
\hline $\begin{array}{l}\text { Schneider et } \\
\text { al., } 2011\end{array}$ & Switzerland & Longitudinal; & 43 & $\begin{array}{l}5-7 \\
6.24 \pm 0.88\end{array}$ & $\begin{array}{l}\text { Separation } \\
\text { anxiety } \\
\text { disorder }\end{array}$ & $\begin{array}{l}\text { Self } \\
\text { Proxy }\end{array}$ & $\begin{array}{l}\text { ILK - Short } \\
\text { version }\end{array}$ & Total score & NR \\
\hline $\begin{array}{l}\text { Sciberras et } \\
\text { al., } 2011\end{array}$ & Australia & Longitudinal & 27 & $\begin{array}{l}6-15 \\
11.52 \pm \\
2.38\end{array}$ & ADHD & Proxy & $\begin{array}{l}\text { PedsQL } 4.0 \\
\text { Generic Core } \\
\text { Scales }\end{array}$ & $\begin{array}{l}\text { Psychosocial health } \\
\text { summary } \\
\text { score }\end{array}$ & NR \\
\hline $\begin{array}{l}\text { Sheldrick et } \\
\text { al., } 2012\end{array}$ & USA & $\begin{array}{l}\text { Cross- } \\
\text { sectional }\end{array}$ & 39 & $\begin{array}{l}12-18 \\
14.8 \pm \mathrm{NR}\end{array}$ & $\begin{array}{l}\text { Autism } \\
\text { Spectrum } \\
\text { Disorders }\end{array}$ & $\begin{array}{l}\text { Self } \\
\text { Proxy }\end{array}$ & $\begin{array}{l}\text { PedsQL } 4.0 \\
\text { Generic Core } \\
\text { Scales }\end{array}$ & $\begin{array}{l}\text { Physical functioning, } \\
\text { Emotional } \\
\text { functioning, Social } \\
\text { functioning, School }\end{array}$ & NR \\
\hline
\end{tabular}




\begin{tabular}{|c|c|c|c|c|c|c|c|c|c|}
\hline & & & & & & & & $\begin{array}{l}\text { functioning, Total } \\
\text { score }\end{array}$ & \\
\hline $\begin{array}{l}\text { Sikora et al., } \\
2012\end{array}$ & $\begin{array}{l}\text { USA and } \\
\text { Canada }\end{array}$ & $\begin{array}{l}\text { Cross- } \\
\text { sectional }\end{array}$ & 3066 & $2-18$ & $\begin{array}{l}\text { Autism } \\
\text { Spectrum } \\
\text { Disorders }\end{array}$ & Proxy & $\begin{array}{l}\text { PedsQL } 4.0 \\
\text { Generic Core } \\
\text { Scales }\end{array}$ & $\begin{array}{l}\text { Physical functioning, } \\
\text { Emotional } \\
\text { functioning, Social } \\
\text { functioning, School } \\
\text { functioning, } \\
\text { Psychosocial } \\
\text { summary score, Total } \\
\text { score }\end{array}$ & $\begin{array}{l}\text { Age as } \\
\text { covariate in } \\
\text { generalized } \\
\text { linear } \\
\text { equation } \\
\text { models }\end{array}$ \\
\hline $\begin{array}{l}\text { Stewart et } \\
\text { al., } 2009\end{array}$ & USA & Longitudinal & 63 & $\begin{array}{l}10-17 \\
13.94 \pm \\
2.27\end{array}$ & $\begin{array}{l}\text { Bipolar I } \\
\text { disorder } \\
\text { (manic or } \\
\text { mixed } \\
\text { episode), } \\
\text { schizophrenia } \\
\text { or } \\
\text { schizoaffective } \\
\text { disorder }\end{array}$ & Proxy & $\begin{array}{l}\mathrm{CHQ}- \\
\text { Parent form }\end{array}$ & $\begin{array}{l}\text { Physical functioning, } \\
\text { Role limitations- } \\
\text { emotional/behavioral, } \\
\text { Role limitations- } \\
\text { physical, Bodily pain, } \\
\text { Behavior, Mental } \\
\text { health, Self-esteem, } \\
\text { General health } \\
\text { perceptions, Parental } \\
\text { impact-emotional, } \\
\text { Parental impact-time, } \\
\text { Family activities, } \\
\text { Family cohesion, } \\
\text { Physical summary } \\
\text { score, Psychosocial } \\
\text { summary score }\end{array}$ & $\begin{array}{l}\text { QL scores } \\
\text { were } \\
\text { examined } \\
\text { separately for } \\
\text { different age } \\
\text { groups: 11-12 } \\
\text { years, 13-15 } \\
\text { years, and 16- } \\
18 \text { years }\end{array}$ \\
\hline $\begin{array}{l}\text { Storch et al., } \\
2007\end{array}$ & USA & $\begin{array}{l}\text { Cross- } \\
\text { sectional }\end{array}$ & 59 & $\begin{array}{l}8-17 \\
11.4 \pm 2.6\end{array}$ & $\begin{array}{l}\text { Gilles de la } \\
\text { Tourette } \\
\text { syndrome or } \\
\text { chronic tic } \\
\text { disorder }\end{array}$ & $\begin{array}{l}\text { Self } \\
\text { Proxy }\end{array}$ & $\begin{array}{l}\text { PedsQL } 4.0 \\
\text { Generic Core } \\
\text { Scales }\end{array}$ & $\begin{array}{l}\text { Physical functioning, } \\
\text { Emotional } \\
\text { functioning, Social } \\
\text { functioning, School } \\
\text { functioning, Total } \\
\text { score }\end{array}$ & $\begin{array}{l}\text { QL scores } \\
\text { were } \\
\text { compared } \\
\text { (MANOVA) } \\
\text { between age } \\
\text { groups (8-11 } \\
\text { years vs. 12- } \\
17 \text { years); } \\
\text { Agreement }\end{array}$ \\
\hline
\end{tabular}




\begin{tabular}{|c|c|c|c|c|c|c|c|c|c|}
\hline & & & & & & & & & $\begin{array}{l}\text { between } \\
\text { informants } \\
\text { was examined } \\
\text { separately for } \\
\text { each age } \\
\text { group }\end{array}$ \\
\hline $\begin{array}{l}\text { Sung et al., } \\
2008\end{array}$ & Australia & $\begin{array}{l}\text { Cross- } \\
\text { sectional; }\end{array}$ & 239 & $\begin{array}{l}5-18 \\
11.7 \pm 3.2\end{array}$ & ADHD & Proxy & $\begin{array}{l}\text { PedsQL } 4.0 \\
\text { Generic Core } \\
\text { Scales } \\
\text { CHQ - } \\
\text { Parent form }\end{array}$ & $\begin{array}{l}\text { Physical summary } \\
\text { score, Psychosocial } \\
\text { summary score, Total } \\
\text { score } \\
\text { Emotional Impact, } \\
\text { Time Impact, and } \\
\text { Family Activities }\end{array}$ & $\begin{array}{l}\text { Age as } \\
\text { covariate in } \\
\text { regression } \\
\text { analyses }\end{array}$ \\
\hline $\begin{array}{l}\text { Topolski et } \\
\text { al., } 2004\end{array}$ & USA & $\begin{array}{l}\text { Cross- } \\
\text { sectional }\end{array}$ & 55 & $\begin{array}{l}11-18 \\
13.9 \pm 1.6\end{array}$ & ADHD & Self & YQOL-R & $\begin{array}{l}\text { Self, Relationship, } \\
\text { Environment, } \\
\text { General QL, Total } \\
\text { score }\end{array}$ & $\begin{array}{l}\text { Age as } \\
\text { covariate in } \\
\text { comparison } \\
\text { analyses } \\
\text { (MANCOVA) }\end{array}$ \\
\hline $\begin{array}{l}\text { Van der } \\
\text { Heijden et } \\
\text { al., } 2007\end{array}$ & $\begin{array}{l}\text { The } \\
\text { Netherlands }\end{array}$ & Longitudinal; & 105 & $\begin{array}{l}6-12 \\
9.20 \pm 2.06\end{array}$ & $\begin{array}{l}\text { ADHD and } \\
\text { chronic sleep- } \\
\text { onset } \\
\text { insomnia }\end{array}$ & Proxy & $\begin{array}{l}\text { TACQOL - } \\
\text { Parent } \\
\text { version }\end{array}$ & Total score & NR \\
\hline $\begin{array}{l}\text { Van Meter et } \\
\text { al., } 2013\end{array}$ & USA & Longitudinal & 54 & $\begin{array}{l}7-13 \\
9.1 \pm 1.59\end{array}$ & $\begin{array}{l}\text { Bipolar } \\
\text { spectrum } \\
\text { disorders }\end{array}$ & $\begin{array}{l}\text { Self } \\
\text { Proxy }\end{array}$ & KINDL & $\begin{array}{l}\text { Physical wellbeing, } \\
\text { Emotional wellbeing, } \\
\text { Self-esteem, Family, } \\
\text { Friends, School }\end{array}$ & $\begin{array}{l}\text { Age as } \\
\text { covariate in } \\
\text { regression } \\
\text { analyses }\end{array}$ \\
\hline $\begin{array}{l}\text { van Steensel } \\
\text { et al., } 2012\end{array}$ & $\begin{array}{l}\text { The } \\
\text { Netherlands }\end{array}$ & Longitudinal & 237 & $\begin{array}{l}7-18 \\
12.10 \pm \\
2.77\end{array}$ & $\begin{array}{l}\text { Autism } \\
\text { Spectrum } \\
\text { Disorders and } \\
\text { anxiety } \\
\text { disorders }\end{array}$ & $\begin{array}{l}\text { Self } \\
\text { Proxy }\end{array}$ & EuroQol-5D & $\begin{array}{l}\text { Mobility, Self-care, } \\
\text { Usual activities, Pain/ } \\
\text { discomfort, } \\
\text { Depression/ anxiety }\end{array}$ & $\begin{array}{l}\text { Main effects } \\
\text { of age }(<12 \\
\text { years vs. }>12 \\
\text { years) and } \\
\text { interaction } \\
\text { effects of Age } \\
X \text { diagnostic } \\
\text { group were } \\
\text { entered in }\end{array}$ \\
\hline
\end{tabular}




\begin{tabular}{|c|c|c|c|c|c|c|c|c|c|}
\hline & & & & & & & & & $\begin{array}{l}\text { regression } \\
\text { analyses }\end{array}$ \\
\hline $\begin{array}{l}\text { Varni et al., } \\
2006\end{array}$ & USA & $\begin{array}{l}\text { Cross- } \\
\text { sectional; }\end{array}$ & 72 & $\begin{array}{l}5-16 \\
10.95 \pm \\
3.13\end{array}$ & ADHD & $\begin{array}{l}\text { Self } \\
\text { Proxy }\end{array}$ & $\begin{array}{l}\text { PedsQL } 4.0 \\
\text { Generic Core } \\
\text { Scales }\end{array}$ & $\begin{array}{l}\text { Physical functioning, } \\
\text { Emotional } \\
\text { functioning, Social } \\
\text { functioning, School } \\
\text { functioning, Total } \\
\text { score }\end{array}$ & NR \\
\hline $\begin{array}{l}\text { Varni et al., } \\
2012\end{array}$ & USA & Longitudinal; & 234 & $\begin{array}{l}6-17 \\
9-47 \pm 3.07\end{array}$ & $\begin{array}{l}\text { Autism } \\
\text { Spectrum } \\
\text { Disorders }\end{array}$ & Proxy & $\begin{array}{l}\text { PedsQL } 4.0 \\
\text { Generic Core } \\
\text { Scales }\end{array}$ & $\begin{array}{l}\text { Emotional } \\
\text { functioning, Social } \\
\text { functioning, } \\
\text { Cognitive } \\
\text { functioning, Total } \\
\text { score }\end{array}$ & NR \\
\hline $\begin{array}{l}\text { Wehmeier et } \\
\text { al., } 2011\end{array}$ & Germany & Longitudinal; & 180 & $\begin{array}{l}6-17 \\
11 \pm 3\end{array}$ & $\begin{array}{l}\text { ADHD and } \\
\text { comorbid } \\
\text { oppositional } \\
\text { defiant or } \\
\text { conduct } \\
\text { disorder } \\
\end{array}$ & Proxy & KINDL-R & $\begin{array}{l}\text { Physical wellbeing, } \\
\text { Emotional wellbeing, } \\
\text { Self-esteem, Family, } \\
\text { Friends, School }\end{array}$ & $\begin{array}{l}\text { Age as } \\
\text { covariate in } \\
\text { comparison } \\
\text { analyses }\end{array}$ \\
\hline $\begin{array}{l}\text { Yang et al., } \\
2007\end{array}$ & Taiwan & $\begin{array}{l}\text { Cross- } \\
\text { sectional; }\end{array}$ & 119 & $6-15$ & ADHD & Proxy & $\begin{array}{l}\text { CHQ - } \\
\text { Parent form }\end{array}$ & $\begin{array}{l}\text { Physical functioning, } \\
\text { Role limitations- } \\
\text { emotional/behavioral, } \\
\text { Role limitations- } \\
\text { physical, Bodily pain, } \\
\text { Behavior, Mental } \\
\text { health, Self-esteem, } \\
\text { General health } \\
\text { perceptions, Parental } \\
\text { impact-emotional, } \\
\text { Parental impact-time, } \\
\text { Family activities, } \\
\text { Family cohesion, } \\
\text { Physical summary } \\
\text { score, Psychosocial }\end{array}$ & $\begin{array}{l}\text { Age as } \\
\text { covariate in } \\
\text { regression } \\
\text { analyses }\end{array}$ \\
\hline
\end{tabular}




\begin{tabular}{|c|c|c|c|c|c|c|c|c|c|}
\hline & & & & & & & & summary score & \\
\hline $\begin{array}{l}\text { Yang et al., } \\
2012\end{array}$ & Taiwan & $\begin{array}{l}\text { Cross- } \\
\text { sectional; }\end{array}$ & 45 & $\begin{array}{l}12-18 \\
14.82 \pm \\
2.62\end{array}$ & ADHD & Self & TQOLQA & $\begin{array}{l}\text { Family, Residential } \\
\text { environment, } \\
\text { Personal competence, } \\
\text { Social relationships, } \\
\text { Physical appearance, } \\
\text { Psychological well- } \\
\text { being, and } \\
\text { Discomfort/pain }\end{array}$ & NR \\
\hline $\begin{array}{l}\text { Zambrano- } \\
\text { Sánchez et } \\
\text { al., } 2012\end{array}$ & Mexico & Longitudinal & 120 & $\begin{array}{l}7-12 \\
9.0 \pm 2.1\end{array}$ & ADHD & Self & AUQUEI & $\begin{array}{l}\text { Family life and social } \\
\text { relationships, } \\
\text { Leisure, Separation, } \\
\text { Function } \\
\text { performance }\end{array}$ & NR \\
\hline $\begin{array}{l}\text { Zinner et al., } \\
2012\end{array}$ & USA & $\begin{array}{l}\text { Cross- } \\
\text { sectional; }\end{array}$ & 211 & $\begin{array}{l}10-17 \\
12.4 \pm 2.2\end{array}$ & $\begin{array}{l}\text { Gilles de la } \\
\text { Tourette } \\
\text { syndrome/ } \\
\text { Chronic tic } \\
\text { disorder }\end{array}$ & $\begin{array}{l}\text { Self } \\
\text { Proxy }\end{array}$ & $\begin{array}{l}\text { PedsQL } 4.0 \\
- \text { Short form }\end{array}$ & Total score & NR \\
\hline
\end{tabular}

ADHD - Attention-deficit and hyperactivity disorder; ANCOVA - Analysis of covariance; ANOVA - Analysis of variance; AUQUEI - Auto-Questionnaire Qualité de Vie Enfant Imagé; CHQ - Child Health Questionnaire; DCGM - DISABKIDS Chronic Generic Module; DUX-25 - Dutch Child AZL-TNO

Quality of Life; HALFS - Health and Life Functioning Scale; ILK - Inventar zur Untersuchung der Lebensqualität von Kindern und Jugendlichen; KINDL Kinder Lebensqualitätsfragebogen questionnaire; MANOVA - Multivariate analysis of variance; MANCOVA - Multivariate analysis of covariance; PedsQL

- Pediatric Quality of Life Inventory; PEMQOL-SF - Pediatric enuresis module to assess quality of life - short form; PQ-LES-Q - Pediatric Quality of Life Enjoyment and Satisfaction Questionnaire; RCT - Randomized Control Trial; SF-36 - Short Form-36 items; TACQOL - TNO-AZL Children's Quality of Life scale; TQOLQA - Taiwanese Quality of Life Questionnaire for Adolescents; YQOL-R - Youth Quality of Life Instrument-Research Version. 


\section{Identification}

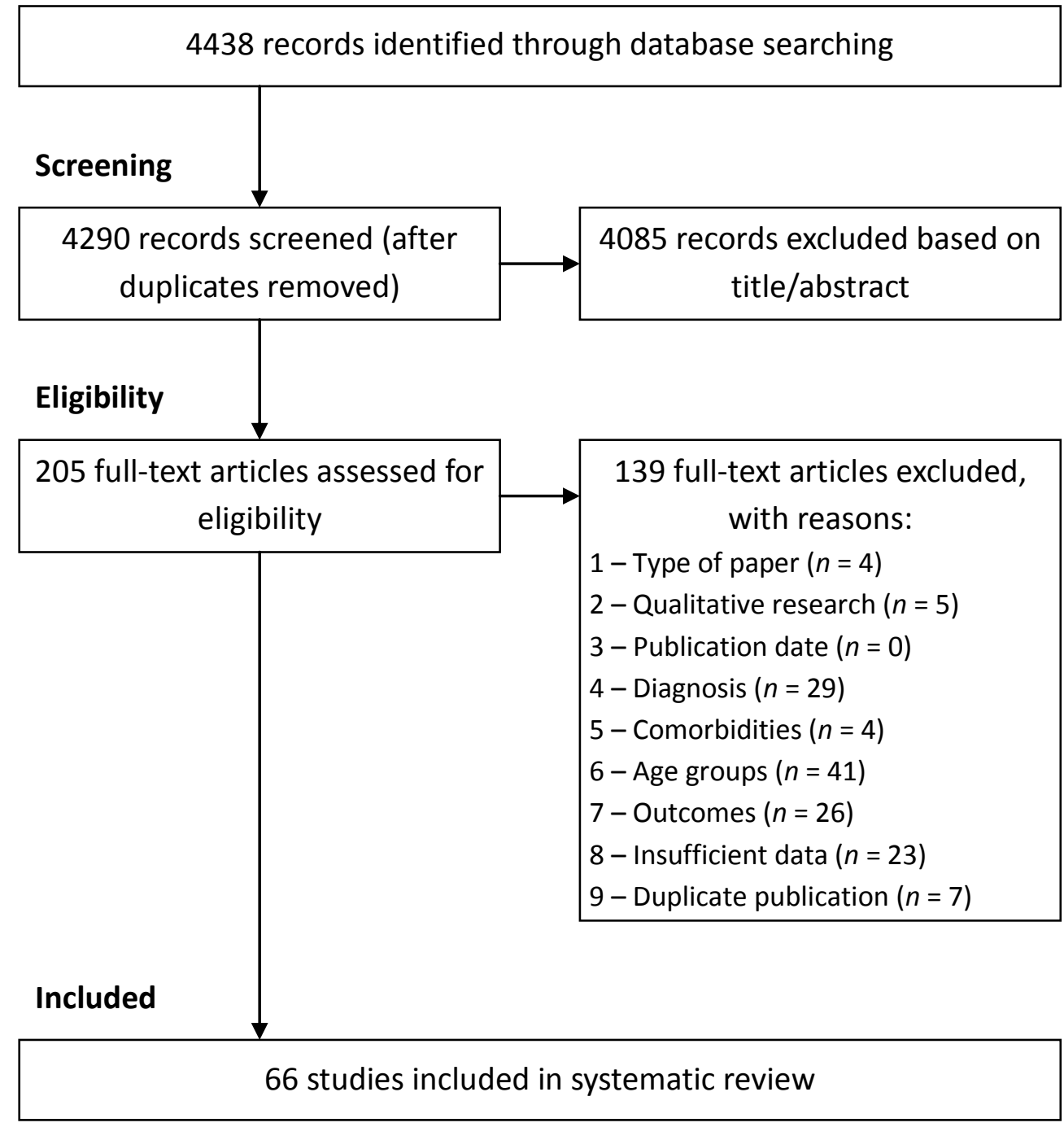

Figure 1. Flow diagram summarizing the study selection process. 


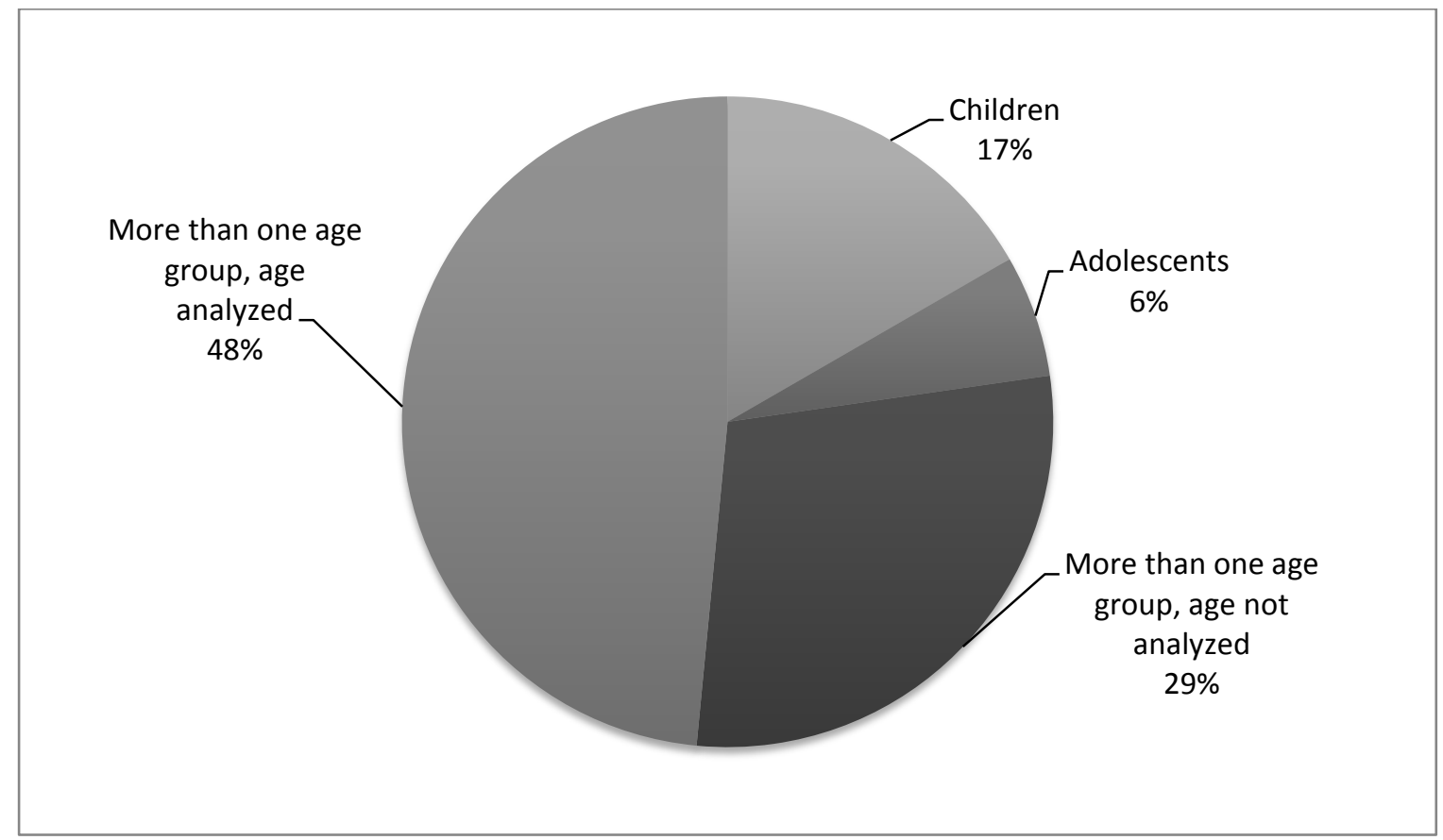

Figure 2. Distribution of participants through age categories 


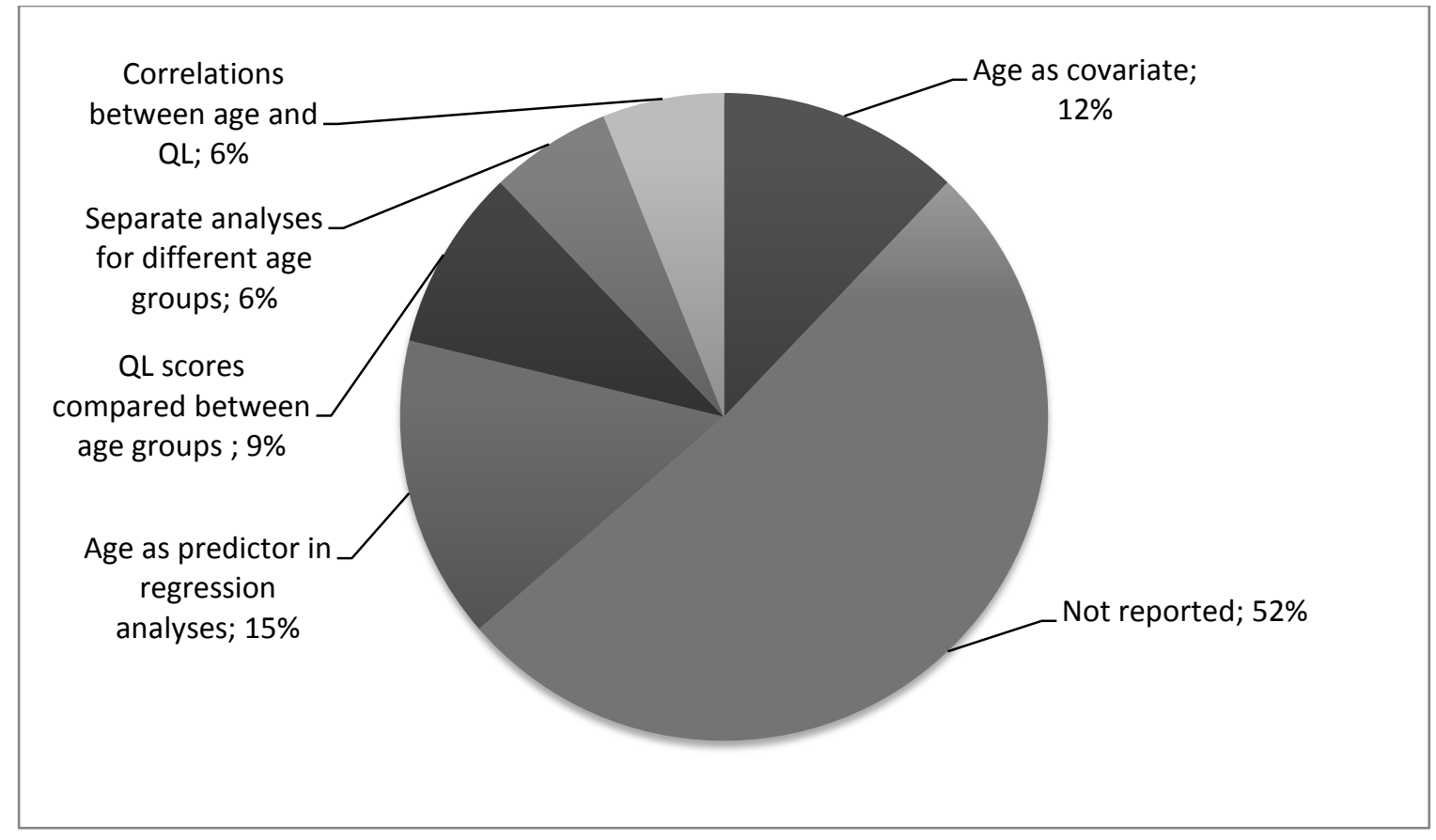

Figure 3. Statistical treatment of age in studies 


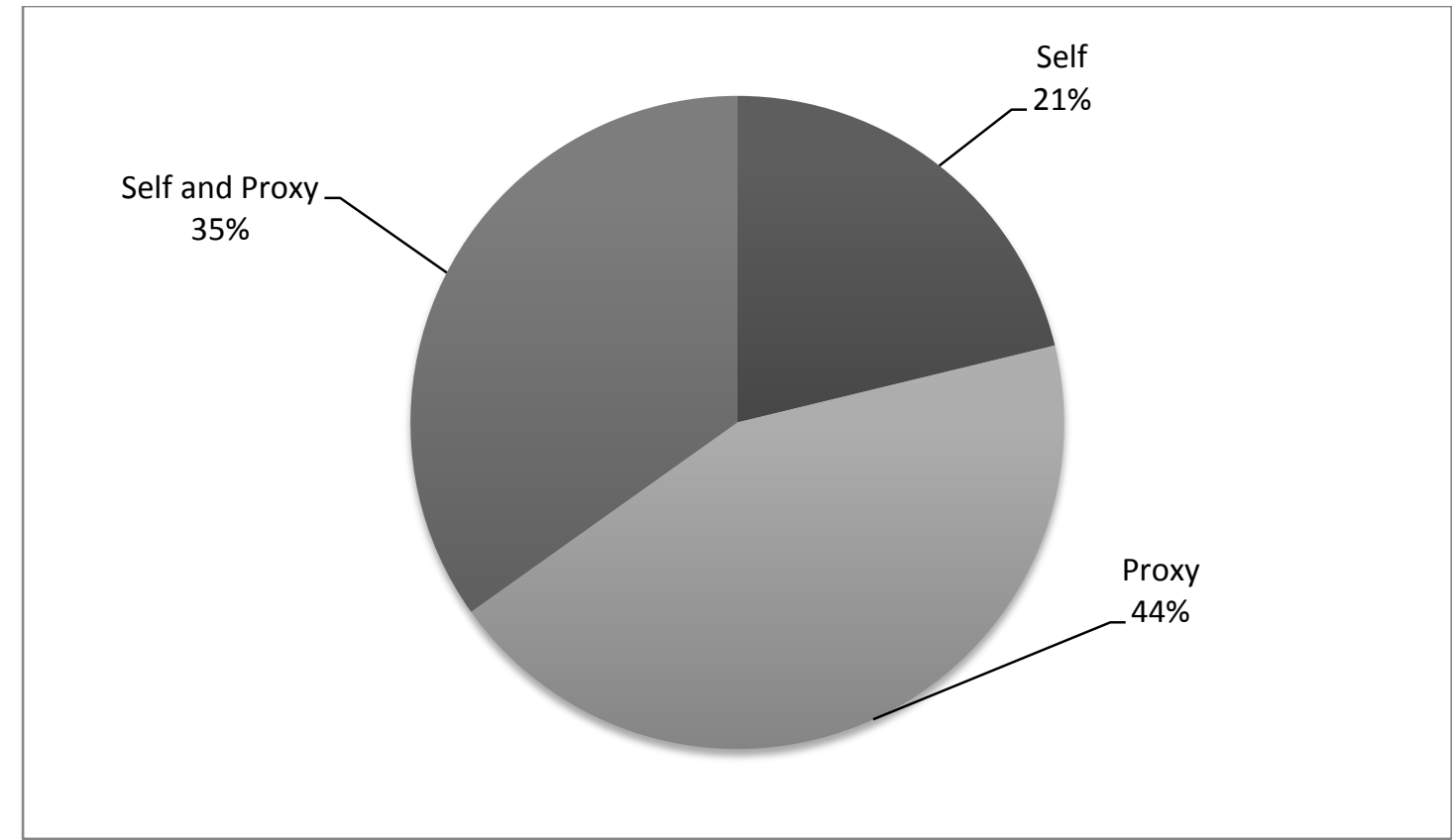

Figure 4. Frequency of the use of self-reports, proxy-reports, or both to assess QL 